\title{
ASEAN5 Bond Market Development: Where Does it Stand? Where is it Going?
}

Joshua Felman, Simon Gray, Mangal Goswami, Andreas Jobst, Mahmood Pradhan, Shanaka Peiris and Dulani Seneviratne 


\title{
IMF Working Paper
}

Asia and Pacific

\section{ASEAN5 Bond Market Development: Where Does it Stand? Where is it Going? \\ Prepared by Joshua Felman, Simon Gray, Mangal Goswami, Andreas Jobst, Mahmood Pradhan, Shanaka Peiris and Dulani Seneviratne}

Authorized for distribution by Mahmood Pradhan

June 2011

\begin{abstract}
Since the Asian crisis, ASEAN5 countries have expended considerable effort in trying to develop their domestic bond markets. Yet today these markets are not much larger, relative to GDP, than they were a decade before. How can we explain this? And does this mean that domestic markets have not, in fact, developed? The paper argues that bond market growth has been held back by a sharp fall in investment rates, which has left firms with little need for bond borrowing. Even so, markets have developed in other ways, to such an extent that substantial amounts of foreign portfolio investment have begun to flow into ASEAN5 bonds. These developments have important ramifications. With the investor base growing and infrastructure investment likely to rise, ASEAN5 bond markets could expand rapidly over the next decade, holding out the prospect that the region could finally achieve "twin engine" financial systems.
\end{abstract}

JEL Classification Numbers: D4, D53, E44, E58, F36, G1, G3

Keywords: bond markets, ASEAN, market development

Author's E-Mail Address: Jfelman@imf.org; sgray@imf.org; mgoswami@imf.org;

Ajobst@imf.org; mpradhan@imf.org; speiris@imf.org; dseneviratne@imf.org

\section{This Working Paper should not be reported as representing the views of the IMF. \\ The views expressed in this Working Paper are those of the author(s) and do not necessarily represent those of the IMF or IMF policy. Working Papers describe research in progress by the author(s) and are published to elicit comments and to further debate.}




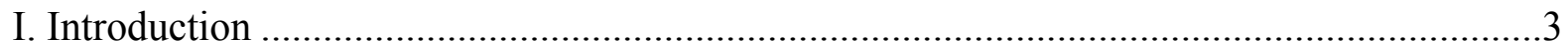

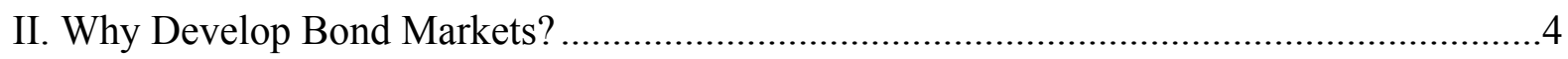

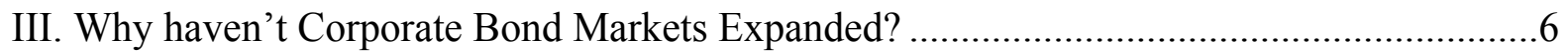

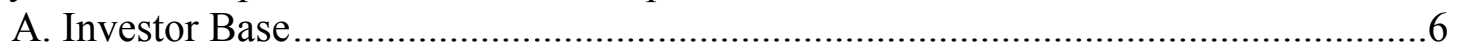

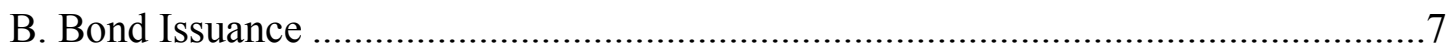

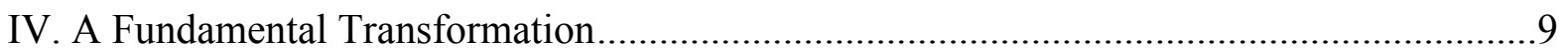

A. Case Studies of Development ..........................................................................

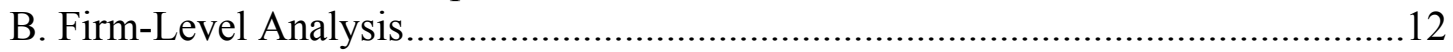

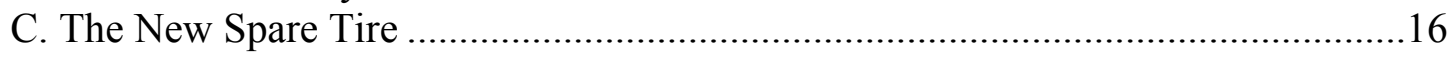

D. The Rise of Foreign Investment ........................................................................18

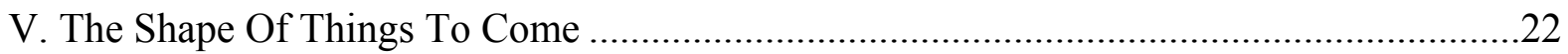

A. Developmental Benefits ………………………….....................................22

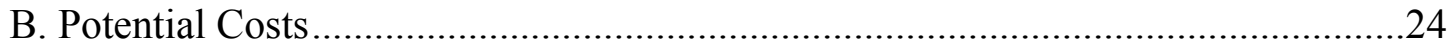

C. Dealing with Off-shore Activity …………………........................................28

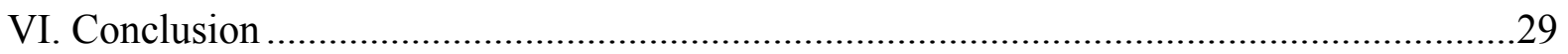

Boxes

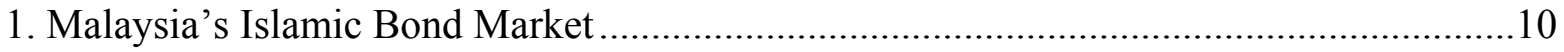

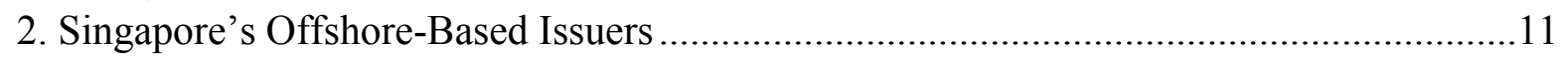

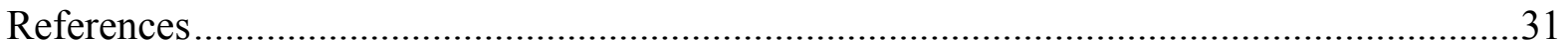




\section{INTRODUCTION}

It has now been a decade since ASEAN launched a major effort to develop its domestic bond markets. ${ }^{1}$ That makes it a good time to take stock, to see what has been accomplished and what still remains to be done. This paper attempts to do just that. ${ }^{2}$

A number of other papers have undertaken such an effort. But there are two important differences between most of these efforts and the current study. First, most of the other studies cast a much wider net, focusing either on bond markets in Emerging Asia as a whole, or on the ASEAN+3. This study focuses exclusively on the ASEAN5, that is to say Indonesia, Malaysia, the Philippines, Singapore, and Thailand.

Second, there are large differences in perspective between this paper and most other studies. Most other papers come to relatively pessimistic conclusions. They note, in particular, that corporate bond markets have not expanded relative to GDP, and conclude that little progress has therefore been made. That is the essence of the argument made by Mieno et. al. (2009). Spiegel (2009) goes even further, expressing doubts about some of the premises underlying the reforms, including the argument propounded by Greenspan (1999) that capital markets can act as a "spare tire" in case the banking system becomes impaired. He claims that this theory has largely been discredited. Nor is Spiegel optimistic about the future, wondering instead whether Asia's bond markets will fade, now that the risk tolerance of the boom years has ended.

This paper reaches very different conclusions. It argues that two critical changes have taken place: bond markets have developed to the point where they have begun to serve as a spare tire in case other parts of the financial system are impaired; and where foreign investors are now eager to expand their investments in local currency fixed income assets. These developments have important ramifications. With the investor base likely to expand as foreign investors devote an increasing portion of their portfolios to emerging market assets, ASEAN5 bond markets could grow much more rapidly over the coming decade, to the point where ASEAN5 could finally develop "twin engine" financial systems. To seize this opportunity, however, pro-active policies will be necessary, both to smooth the development path and minimize the attendant risks, such as market volatility.

The plan of the paper is as follows. The next section recalls why this initiative was so important to ASEAN, and outlines the sweeping reforms that countries have introduced. Section three addresses the puzzle of why, despite these efforts, ASEAN5 bond markets have not expanded relative to GDP. Section four then focuses on other metrics of development, arguing that these suggest that a remarkable transformation of ASEAN bond markets is in

\footnotetext{
${ }^{1}$ ASEAN refers to the Association of Southeast Asian Nations. ASEAN+3 includes China, Japan, and Korea.

2 This and a companion paper (“Developing ASEAN5 Bond Markets: What Still Needs to be Done?”) were presented to an ASEAN5 Deputy Governors' seminar held in Bangkok on November 5, 2010. The final versions benefit from discussion during that seminar and subsequent comments from the ASEAN5 central banks. The authors wish to express their gratitude for this helpful input.
} 
fact underway. Section five considers some of the implications of this transformation. Section six concludes.

\section{WHY DEVELOP BOND MARKETS?}

Across the globe, emerging markets have placed great emphasis on developing their bond markets in recent years. Why have they done so? Essentially, because the financial sector plays a vital economic role, by channeling funds from those who are saving to those who are investing. The more efficiently it performs this function, the lower the cost of capital will be to the real sector, the faster the economy will grow, and the sooner living standards will reach advanced country levels.

What is true for financial markets as a whole applies to bond markets in particular. That's because bond markets can play an especially important role in financing large investment projects. Such projects tend to be risky and take time before they yield returns, characteristics that make investors reluctant to finance them. But bond markets can spread these risks over a large number of holders of securities. Moreover, because bond contracts (unlike loans) are designed to be traded, they allow investors to transfer the risks to others when they feel the need to do so, even before the projects are completed. The combination of these two characteristics - the scope for risk-sharing and risk-shedding - means that bond investors are much more willing to make large, long-term commitments than banks, which are constrained by limits on how much maturity transformation they can engage in.

In addition, bond markets are well-suited for furthering regional development. Indeed, a prime factor behind the development of bond finance in the United States a century ago was that it allowed savings in the more mature economy of the east coast to be channeled to meet the demands of the developing west coast economy, in a way which the banking system could not. The same may now be true, mutatis mutandis, for the ASEAN countries. Bond markets face fewer constraints to cross-border flows than banks: there are no foreign exchange open position limits, no maturity mismatch limits, nor any capital requirements, all of which (appropriately) apply to depository institutions.

Beyond these general principles, there are particular reasons why ASEAN has put so much emphasis on developing bond markets over the past decade. These reasons stem from the consensus diagnosis of what happened in 1997. According to this view, the crisis could be traced in large part to several underlying problems in ASEAN's financial systems: ${ }^{3}$

- $\quad$ Finance systems were extremely bank-centric, which meant that most of the financial risks were being concentrated in the banking system - and there was no alternate channel of intermediation that could be used if the banks once again encountered difficulty.

\footnotetext{
${ }^{3}$ See, for example, Eichengreen (2006).
} 
- $\quad$ Borrowing had suffered from a double mismatch, since long-term domestically oriented investment projects were being funded through short-term and foreign currency borrowing.

- $\quad$ Countries in the region were perceived to be excessively dependent on volatile capital inflows, a situation that struck many observers as ironic since the region had an abundance of domestic saving.

Observers further argued that all three of these problems could be solved by developing domestic bond markets. Vibrant bond markets would create another financing channel, a spare tire that firms could use in case banks once again encountered difficulties. And because domestic bonds would be long-term and in local currencies, they would eliminate the double mismatch problem. Finally, with more active domestic bond markets, firms could reduce their dependence on foreign capital markets.

Based on this diagnosis, ASEAN has put considerable effort over the past decade into developing its bond markets. The ASEAN+3 created the Asian Bond Market Initiative (ABMI), which established several working groups to study the issues and make recommendations. The Asian Development Bank also established a study program, and created Asia Bonds Online so that researchers and market participants could easily find key information about local currency markets. ${ }^{4}$ The Executives' Meeting of East Asia Pacific Central Banks (EMEAP) created pan-Asian bond funds to facilitate regional investment.

For a review of ASEAN's reform efforts, see the companion paper, "Developing ASEAN5 Domestic Bond Markets: What Still Needs to be Done?" But just to take two examples, characteristic of the reforms around the region:

- $\quad$ The Philippines introduced a new Securities Regulation Code (SRC), institutionalized delivery-versus payment through a Real Time Gross Settlement System (RTGS), and launched an inter-dealer platform to encourage exchange trading of fixed income instruments.

- $\quad$ Malaysia has established a facilitative regulatory environment, including Foreign Exchange Administration rules that include no withholding tax, no capital gains tax, and no restrictions on investing in Malaysian ringgit bonds. In addition, a wide range of foreign exchange and interest rate hedging instruments have been introduced, contributing to the

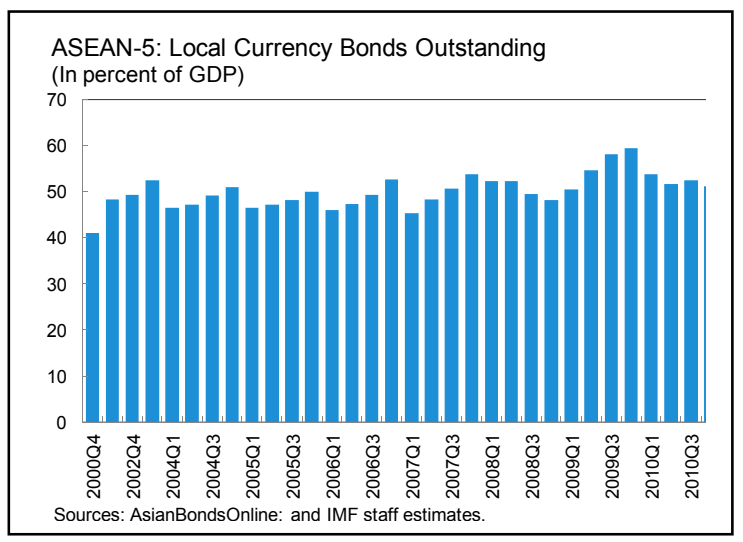

\footnotetext{
${ }^{4}$ Nonetheless, data problems remain an issue. In some cases, AsiaBondsOnline data differ widely from those available from other sources, such as the Bank for International Settlements (BIS). Also, data for some variables is not available for all countries, hindering ASEAN-wide analysis.
} 
deepening and growing sophistication of the Malaysian bond market.

Despite these sweeping reforms, however, ASEAN5 bond markets have not grown, relative to GDP. For most of the past decade the stock of local currency bonds outstanding has fluctuated around roughly 50 percent of regional GDP. ${ }^{5}$ As a result, ASEAN5 has not been able to expand its share in the emerging markets bond universe. A decade ago, ASEAN5's domestic debt accounted for about one-fifth of total emerging market domestic debt securities, excluding those from China; today, the fraction is exactly the same. If the rapidly developing bond market in China were to be included amongst the emerging market total, ASEAN5's share would have fallen, to about one-tenth.

Why haven't ASEAN5 bond markets grown? In part, because the bulk of ASEAN5 local currency bonds - around 35 percent of GDP - are issued by governments. And for most of the past decade budget deficits remained low, so there was little need for them to issue additional debt. But even the size of the corporate bond markets has remained remarkably stable, hovering around just 15-18 percent of GDP. This presents a profound puzzle. Why haven't corporate debt markets expanded? And does that mean they have not really developed? Let's take these questions in turn.

\section{WhY HAVEN'T CORPORATE BOND MARKETS EXPANDED?}

At the outset of ASEAN's push to develop bond markets, some observers hoped that the region could follow the same path as Latin America. In that region, bond markets had been propelled forward by the rapid development of contractual savings schemes, such as pension funds. As these schemes expanded, their demand for long-term domestic currency assets increased, which in turn encouraged firms to respond by issuing more bonds. But this dynamic failed to materialize in the ASEAN5. To understand why, consider first the demand side of the market, that is to say the investor base. Has it failed to develop?

\section{A. Investor Base}

\footnotetext{
${ }^{5}$ For a discussion of what happened in 2009, see Section IV below.
} 
In fact, the ASEAN5 domestic investor base has expanded considerably over the past decade. But the expansion did not come from the expected source. To the contrary, the contractual savings schemes have shown remarkably little growth. In Indonesia, the Philippines, and Thailand, the assets of pension funds amounted to less than 10 percent of GDP in 2000, and they remain at that level today. Pension fund assets in Malaysia and Singapore are relatively high by emerging market standards, but they have not shown any trend growth, either. Meanwhile, assets of life insurance companies have stagnated at low levels in the Philippines and Indonesia, while rising by only a few percentage points in Malaysia and Thailand. As a result, the share of bonds held by contractual savings institutions has diminished considerably over time. In Malaysia, for example, nearly threequarters of government bonds were held by the social security institutions in 2000. But ten years later their share has fallen to less than one-third, while domestic financial institutions now account for the bulk of the holdings.

\section{What are these domestic financial}

institutions? Banks, of course, in large part. But increasingly, domestic mutual funds. A decade ago, this sector was tiny, with total assets of less than $\$ 5$ billion, accounting for less than 5 percent of GDP in all the five countries. But especially starting in the mid-

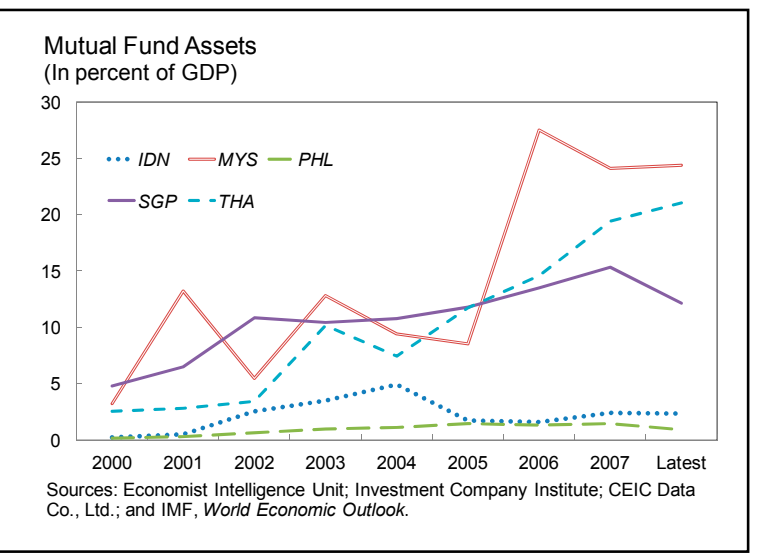
2000 s, they have exploded in size in every country except Indonesia, to the point where in Thailand and Malaysia their assets now amount to more than $\$ 50$ billion, or 20 and 25 percent of GDP, respectively. Largely as a result, domestic financial institutions now hold two-fifths of Malaysian government bonds, double the share they held in 2000.

But this only deepens the mystery. If the investor base has expanded, then why haven't firms met this increase in demand by providing more supply?

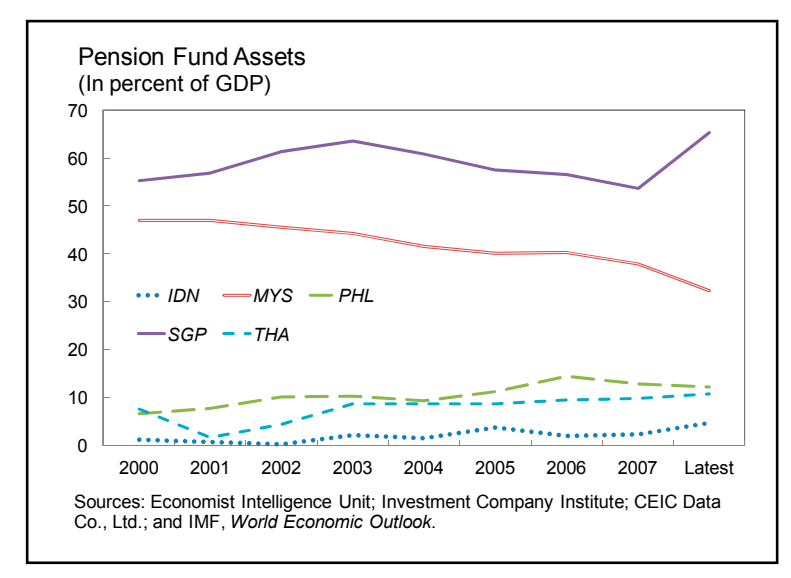

expansion projects, firms relied increasingly on external finance, boosting their leverage ratios to exceptionally high levels. After the Asian crisis, however, this process shifted

\section{B. Bond Issuance}

The main reason why firms failed to issue more bonds relates to the profound change in the macroeconomic environment after the Asian crisis. During the early 1990s, investment reached 40 percent of GDP in some ASEAN5 countries, as firms raced to expand their shares of booming markets. To fund their

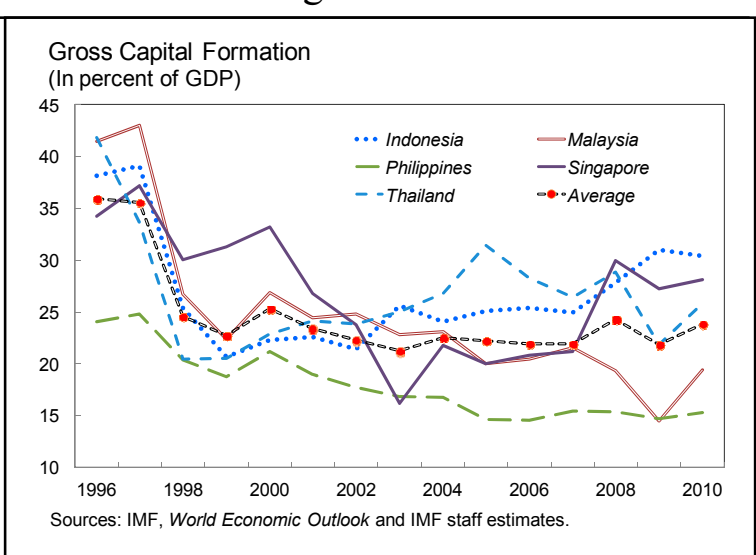


into reverse. Firms became much more cautious, reducing economy-wide investment rates to around 25 percent of GDP in the late 1990s before increasing them again, gradually and partially, in most countries during the global boom of the mid-2000s. In the Philippines and Malaysia the trends were even more striking, as investment ratios generally continued to fall throughout the period, reaching around 15-20 percent of GDP during the mid-2000s.

The Asia-Pacific Regional Economic Outlook (2010) has explored the roots of this trend. It found that the main causes of the investment decline were lower returns, greater uncertainty, and altered perceptions of the ease of doing business. Over the past decade, growth in Asia has been slower and much more volatile than earlier, reducing firms' incentive to expand capacity. At the same time, investors have become more cautious in extending funds to businesses, as perceptions of business climate have deteriorated. In other words, causation has gone both ways: the decline in investment has reduced the demand for finance, while financial constraints have also discouraged investment.

At the same time, firms found alternative ways to fund their investment projects. As part of the post-Asian crisis changes, firms strove to increase their profitability, and succeeded in doing so. They were consequently able to fund a much larger portion of their diminished investment needs from their own internal cash generation. At the same time, the crisis also led to a shift in the types of investment, away from construction, which is typically financed by borrowing; and towards manufacturing for export, which is financed in a much wider variety of ways. In particular, ASEAN manufacturing companies tend to finance themselves through equity, including direct equity investments. Teranishi, Fukuda, and Liu (2007) found that companies from Thailand, Malaysia, and Indonesia rely for their long-term funding much more heavily on equity finance and - strikingly - much less on banks, than do corporations in advanced countries. Mieno (2009) found that capital accounts represented 53 percent of the balance sheet for listed Malaysian corporations, while bank borrowing accounted for only 14 percent; the figures for Thai corporations were similar. Unsurprisingly, then, aggregate figures for the ASEAN5 show that equities account for nearly two-thirds of corporate domestic financing, with bank credit and bonds splitting the remainder.

A further important structural factor is the large role played, within the manufacturing sector, by foreign-invested companies. In a series of studies Mieno et. al. (2008, 2009) have argued that since the mid-1980s, when ASEAN became an increasingly important base for multinational manufacturing production, foreign corporations have become an increasingly important funding channel for local companies. Mieno notes, for example, that half of the major 1,100 listed and non-listed corporations in Thailand now have foreign ownership participation. And he finds that the higher the share of foreign ownership, the lower the reliance on bank lending. Instead, these firms tend to rely on internal funding from their parent corporations.

Summing up, the expansion of the domestic investor base created an opening for ASEAN5 corporate bond markets. But firms failed to seize this opportunity, because they had little need to issue over the past decade. Does this failure to expand mean that markets have not developed? Not at all. Development has many dimensions, and on many of these metrics, progress is clear. In fact, ASEAN5 markets have been fundamentally transformed. 


\section{A Fundamental Transformation}

To track this transformation, we consider first some case studies, which enable us to see clear links between policy initiatives and market development. From this, we proceed to a firm level analysis, to assess whether, in a well-defined sense, it has become easier for firms to access ASEAN5 corporate bond markets. Then, we consider two of the more dramatic manifestations of the transformation. Specifically, the corporate bond market has developed into a "spare tire" that corporates can use when other parts of the financial system come under stress, while foreign investors have become eager to purchase domestic bonds.

\section{A. Case Studies of Development}

Consider again the size of ASEAN5's bond markets. While these markets may not have expanded over the past decade, they nonetheless remain quite sizeable in some cases. According to BIS data, the local currency markets in Thailand and Singapore are reasonably large for EMs, while Malaysia's market is larger than most. ${ }^{6}$ These markets also boast a sophisticated infrastructure. (See Developing ASEAN5 Domestic Bond Markets: What Still Needs to be Done?) In view of the analysis in Section III, one could turn the original question on its head and ask how these countries managed to

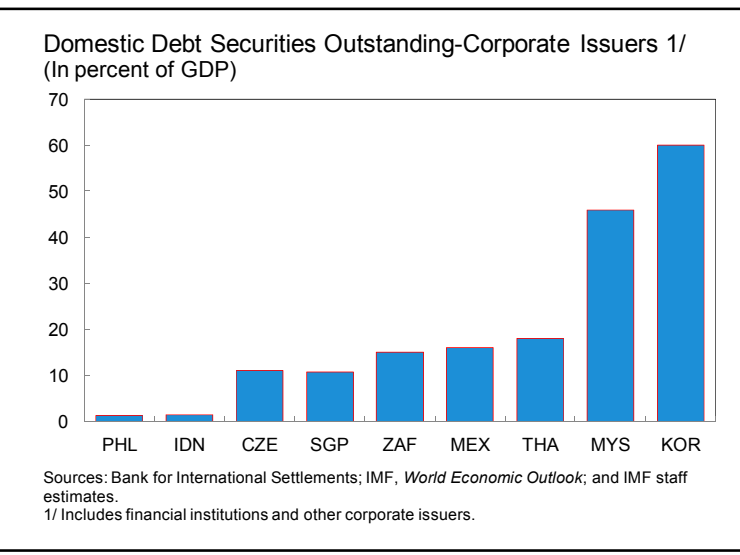
sustain such large and sophisticated bond markets in the face of shrinking investment. The answer lies in policy initiatives. Malaysia's market has been boosted by efforts to promote the issuance of Islamic bonds (Box 1), while Singapore has managed to overcome its relatively narrow domestic issuer base by encouraging overseas firms to issue in the local currency market (Box 2).

\footnotetext{
${ }^{6}$ Data on market size varies widely, depending on the precise definition employed. According to BIS data, Thailand's local currency corporate bond market amounts to around 20 percent of GDP, but under the Asia Bonds Online definition it is only 12 percent of GDP.
} 


\section{Box 1. Malaysia's Islamic Bond Market}

Over the past decade, Malaysia has developed a burgeoning market in sukuk, or shari'ah-compliant bonds. Unlike conventional bonds with fixed coupon payments, sukuk are structured as participation certificates that provide investors with a share of asset returns, making them compatible with the Islamic prohibition of interest payments. As a result, they have become increasingly popular, both domestically and amongst investors from other Islamic nations. The stock of sukuk as a ratio to GDP has doubled since 2001, exceeding 28 percent by 2008. This expansion has given Malaysia a dominant position in the global market, with Malaysian issuances accounting for more than two-thirds of the total $\$ 130$ billion sukuk outstanding.

This success has been rooted in an array of policy initiatives. In 2000, the government laid out a ten-year Capital Market Master Plan for developing the bond market, both sukuk and conventional. Subsequently:

- $\quad$ Cagamas Berhad, the National Mortgage Corporation, in 2004 issued the world's first rated Islamic Residential Mortgage-Backed Sukuk Musyarakah, of RM 2.05 billion.

- The registration of Islamic banks was eased, and capital controls were relaxed for multi-currency transactions as a part of Islamic banking activities.

- Tax exemptions have been granted for banks until 2016 on income earned from international banking and takaful (Islamic insurance) operations in foreign currencies.

- $\quad$ The government has also provided assistance in placing sukuk via the Malaysia International Islamic Financial Centre (MIFC).

The private sector (including state-owned enterprises) has responded to these incentives with alacrity. Sukuks now account for more than half the private debt securities outstanding, double their share of a decade ago. However, the expansion of this market has not been enough to compensate for the shrinkage of the conventional bond market (measured relative to GDP). As a result, the overall ratio of corporate bonds to GDP has actually declined by about 10 percentage points since 2001 , to 38 percent of GDP, mainly because investment has fallen sharply over this period, reducing the need for bond finance.

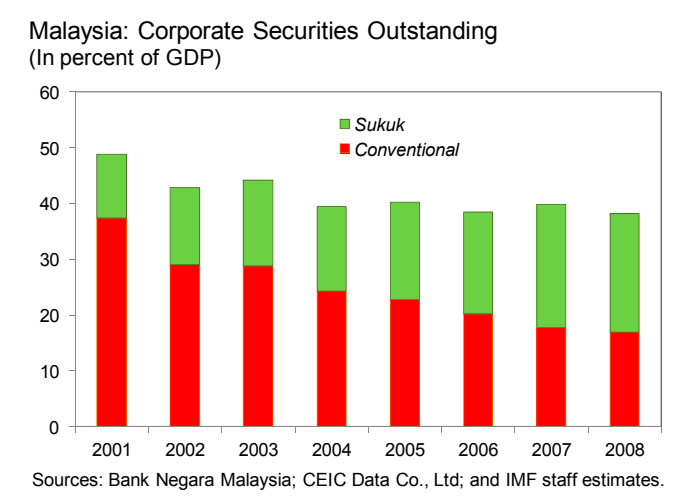




\section{Box 2. Singapore's Offshore-Based Issuers}

Singapore has developed an active corporate debt market by encouraging foreignbased firms to issue locally, compensating for the narrow domestic issuer base. Domestic issuance of Singapore dollar bonds exceeded S\$16 billion in 2009, of which one-quarter was attributable to offshore-based companies

A number of factors encourage issuance by offshore companies. Foremost among them is the relative ease by which borrowers can tap the market. Legal and regulatory impediments are virtually nonexistent. Disclosure documents are quite simple and tend to be Regulation S style as Singapore dollar corporate bonds are largely marketed to wholesale buyers only, which simplifies reporting, including prospectus obligations. ${ }^{1}$

Issuance is also encouraged by the tax framework. Issues undertaken locally have no filing requirements other than to file a tax return to the Monetary Authority of Singapore (MAS) and the Inland Revenue Authority of Singapore after the issue date. Singapore Exchange submission for listed bonds is typically expedient and straight forward. The above factors make the Singapore dollar market very cost competitive compared to the alternatives, such as U.S. Regulation S or 144A issues.

Regulatory measures adopted in July 2009 have also helped. MAS implemented a two-part framework in 2009 to anchor AAA-rated issuers in the Singapore dollar bond market. First, AAA-rated Singapore dollar debt securities issued by sovereigns, supranationals and sovereign-backed corporate would be accepted as collateral under the MAS Standing Facility. Second, banks would be allowed to treat these securities as regulatory liquid assets, applying the same haircut as SGS. Following the implementation of the framework, the Singapore dollar debt market saw a surge in supranational issuances in 2009, totaling S\$1.4 billion. Issuers included Kreditanstalt fur Wiederaufbau (KfW), International Bank for Reconstruction \& Development (IBRD) and African Development Bank (AfDB). In July 2010, MAS extended the list for issuers to include AAA-rated and Basel zero risk-weighted public sector entities.

Finally, foreign issuers are attracted by the fact that Singapore is an international financial center, with a large investor base, including foreign asset managers, insurance companies, banks, and private banks.

\footnotetext{
1/ Regulation S is a "safe harbor" provision of the U.S. Securities Act, defining when a security is deemed to be issued abroad and therefore not subject to the registration requirements for locally issued securities.
} 


\section{B. Firm-Level Analysis}

In any case, market development cannot be measured solely on the basis of size. Two of the most important alternative measures are concentration and significance, where the latter refers to the size of issues as a proportion of firm balance sheets. Measured this way, bond market development can be conceived as following a certain pattern. Initially, when the market is at a very early stage, only a few firms will be large enough or financially wellregarded enough (with a long track record and audited public accounts) to issue. Moreover, because there are sizeable fixed costs to issuing bonds, and because firms want to establish liquid benchmark issues, the size of these initial issues is normally large relative to firm balance sheets. But over time, as markets and economies develop, concentration ratios tend to fall. Markets will no longer be dominated by a few large issuers, or a few large bond issues, since more and more firms are able to issue. In addition, the significance of bond issues will also tend to decline, partly because as issuance becomes routine, firms will tend to issue frequent smaller amounts rather than occasional large amounts and because these minimum amounts will become small relative to the size of growing balance sheets.

\section{The process can be depicted graphically as follows:}

\section{Bond Market Development Matrix}

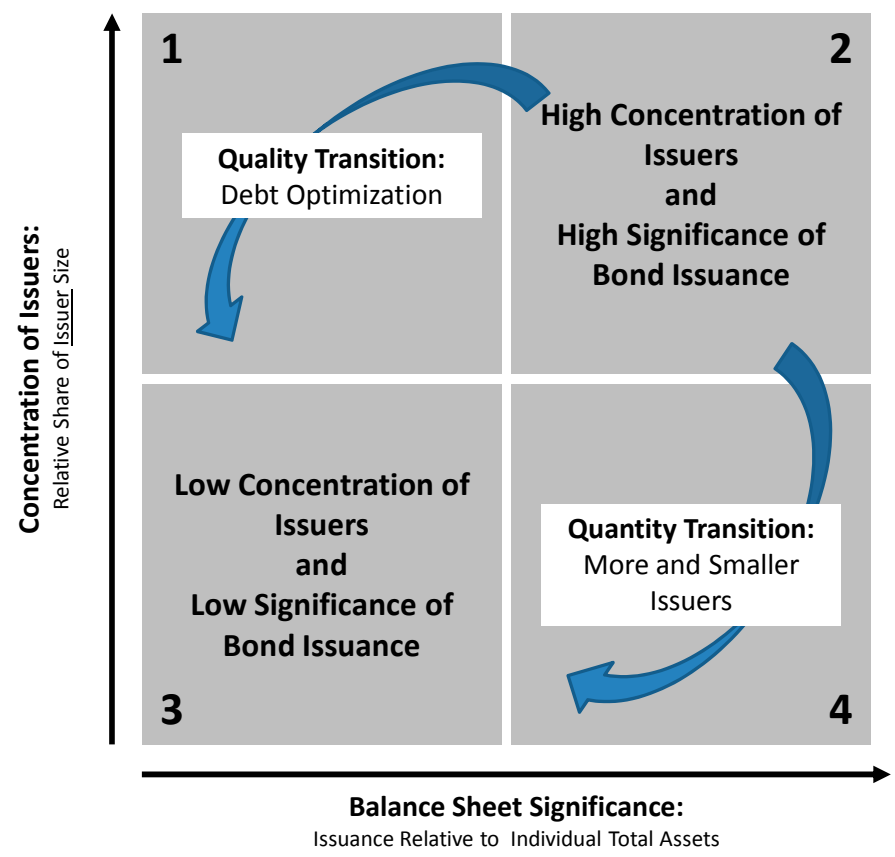

Initially, the market starts off in the second quadrant, with high concentrations (in this diagram, the concentration of issuers) and high significance. But gradually as the market develops, it moves into the third quadrant, with low concentration and low significance.

So much for theory. What is the evidence for the ASEAN5? Some key indicators are provided in the table below, based on local currency issuance by the non-financial private sector. Because the sample sizes for Philippines, Singapore, and Indonesia are very small, it 
is perhaps best to focus on Malaysia and Thailand. ${ }^{7}$ In these two markets, one can see some clear progress: the amount of issuance has been increasing steadily; the number of issues and issuers has increased sharply; and with the influx of new issues, the average maturity has shortened.

\begin{tabular}{|c|c|c|c|c|c|c|c|c|c|c|c|c|c|c|}
\hline \multicolumn{15}{|c|}{ Local Currency (LCY) Non-financial Corporate Bond Issuance: Sample Analysis } \\
\hline & \multicolumn{7}{|c|}{ issuance (in USD billions) } & \multicolumn{7}{|c|}{ issuance/total assets ratio (median, in percent) } \\
\hline & IDN & MYS & $\mathrm{PHL}$ & THA & SGP & $B R A$ & KOR & IDN & MYS & $\mathrm{PHL}$ & THA & SGP & $B R A$ & KOR \\
\hline 2000 & & 0.9 & $\ldots$ & & $\overline{1.2}$ & & $\overline{18.8}$ & $\ldots$ & 36.7 & & & $\overline{10.4}$ & & $\overline{3.9}$ \\
\hline 2005 & 0.7 & 4.3 & 1.1 & 2.6 & $\ldots$ & 1.2 & 20.5 & 6.7 & 11.0 & 18.2 & 6.3 & $\ldots$ & 2.5 & 5.6 \\
\hline 2009 & 1.5 & 5.7 & 2.2 & 8.1 & 0.1 & 12.6 & 47.8 & 3.5 & 5.6 & 4.9 & 9.0 & 7.6 & 5.4 & 5.8 \\
\hline \multirow[t]{3}{*}{2010} & 1.1 & 2.4 & 1.0 & 3.0 & 0.2 & 11.8 & 19.5 & 3.1 & 5.3 & 9.0 & 8.6 & 17.6 & 8.0 & 4.9 \\
\hline & \multicolumn{7}{|c|}{ average maturity (in years) } & \multicolumn{7}{|c|}{ number of issues/issuers } \\
\hline & IDN & MYS & $\overline{\mathrm{PHL}}$ & THA & SGP & $B R A$ & KOR & IDN & MYS & $\mathrm{PHL}$ & THA & SGP & $B R A$ & KOR \\
\hline 2000 & & 13.5 & & & $\overline{4.5}$ & & 3.0 & & $54 / 6$ & & & $\overline{19 / 12}$ & & $970 / 189$ \\
\hline 2005 & 6.0 & 9.2 & 5.8 & 9.2 & $\ldots$ & 7.4 & 2.5 & $6 / 6$ & $198 / 38$ & $6 / 6$ & $16 / 6$ & $\ldots$ & 13/11 & $1,160 / 206$ \\
\hline 2009 & 3.9 & 6.6 & 5.2 & 4.6 & 4.6 & 5.0 & 2.4 & $45 / 20$ & $158 / 50$ & $23 / 11$ & $83 / 36$ & $14 / 5$ & $73 / 52$ & $2,068 / 504$ \\
\hline \multirow[t]{3}{*}{2010} & 5.6 & 2.1 & 6.0 & 4.3 & 5.7 & 5.1 & 2.6 & $23 / 9$ & $175 / 70$ & $4 / 3$ & $71 / 30$ & $8 / 5$ & $87 / 49$ & $670 / 188$ \\
\hline & \multicolumn{7}{|c|}{ concentration of issuance volume $1 /$} & \multicolumn{7}{|c|}{ concentration of issuer assets $2 /$} \\
\hline & IDN & MYS & $\mathrm{PHL}$ & THA & SGP & $B R A$ & KOR & IDN & MYS & $\mathrm{PHL}$ & THA & SGP & $B R A$ & KOR \\
\hline 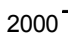 & & 0.08 & & & 0.10 & & 0.04 & $\ldots$ & 0.01 & & & 0.99 & & 0.04 \\
\hline 2005 & 0.59 & 0.04 & 0.43 & 0.19 & $\ldots$ & 0.11 & 0.02 & 0.26 & 0.03 & 0.16 & 0.14 & $\ldots$ & 0.05 & 0.05 \\
\hline 2009 & 0.12 & 0.06 & 0.11 & 0.06 & 0.51 & 0.03 & 0.02 & 0.12 & 0.07 & 0.03 & 0.03 & 0.52 & 0.03 & 0.02 \\
\hline 2010 & 0.08 & 0.04 & 0.26 & 0.10 & 0.15 & 0.03 & 0.04 & 0.12 & 0.09 & 0.16 & 0.13 & 0.03 & 0.07 & 0.03 \\
\hline
\end{tabular}

Sources: Bloomberg, Worldscope, Moody's KMV as w ell as national stock exchanges.

Note: Data excludes issuance by state-ow ned enterprises, all financial institutions and international organizations. 2010 Information includes Q1 and Q2 available data. $1 /$ logarithmic and re-scaled, standardized Herfindahl-Hirschman Index $(H H)$ : Issuance Concentration $=\log \left(\min \left(H H_{i}, H H_{i}-\min \left(H H_{N}\right)\right) \in[0,1]\right.$, where $H H_{1}=(\Sigma(s h a r e$ of issuance amount by issuer $i$ in a given year $)^{2}-1 /$ total number $N$ of issuers $\left.i\right) /(1-1 /$ total number $N$ of issuers $i)$. The closer the value to zero, the less concentrated the annual issuance of corporate bonds.

2/ logarithmic and re-scaled, standardized Herfindahl-Hirschman Index $(\mathrm{HH})$ : Issuer Concentration=log $\left(\min \left(\mathrm{HH}_{\mathrm{i}}, \mathrm{HH} \mathrm{H}_{\mathrm{i}}-\min \left(\mathrm{HH}_{\mathrm{N}}\right)\right) \in[0,1]\right.$, where $\mathrm{HH} \mathrm{H}_{\mathrm{i}}=(\Sigma(\mathrm{balance}$ sheet assets of issuer $i$ relative to total balance sheet assets of all issuers in a given year $)^{2}-1 /$ total number $N$ of issuers $\left.i\right) /(1-1 /$ total number $N$ of issuers $i)$. The closer the value to zero, the less concentrated the issuer size.

At the same time, progress in reducing concentration and significance (of individual issues) has been mixed. On the positive side, concentration - whether measured by issuance (e.g., a few large bonds) or by issuers (e.g., a few large companies) - in Malaysia is now down to the levels of Brazil and Korea. But concentration in other countries remains high. Similarly, the significance of new issues (issuance relative to balance sheet size) has diminished in Malaysia to the levels of the most advanced emerging markets, but remains high in other countries.

The two metrics interact in the expected way. For example, controlling for concentration, the Philippines and Malaysia tend to have higher levels of significance. That is to say, the average issuance volume relative to issuer balance sheets is higher in countries with less developed bond markets, as the theory would predict.

\footnotetext{
${ }^{7}$ Bond issuance (and balance sheet information (total assets)) data were obtained for five ASEAN countries as well as two emerging market comparator countries (Brazil and Korea). Bond issuance data include all local currency-denominated non-financial, private sector transactions during each sample year $(2000,2005,2009$, and the first two quarters of 2010) as reported in Bloomberg and Dealogic. Note that issues by financial companies and Special Purpose Vehicles were excluded, in the latter case because these entities are levered financing vehicles, rather than operating companies. As a result, the sample size for Singapore is too small to be reliable.
} 


\section{Corporate Bond Issuance Relative to Total Assets Conditional on Issuer Concentration}

\section{0, first half}

Indonesia

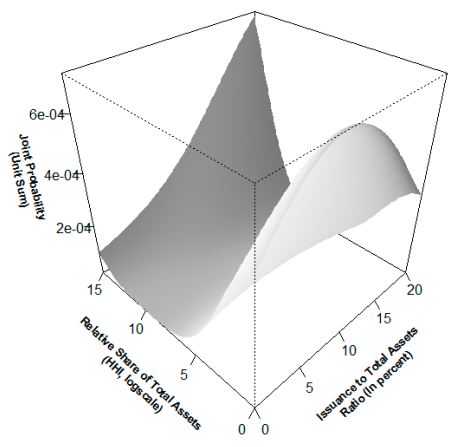

Philippines

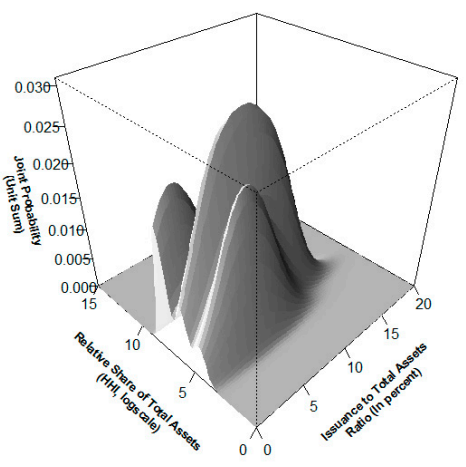

Brazil

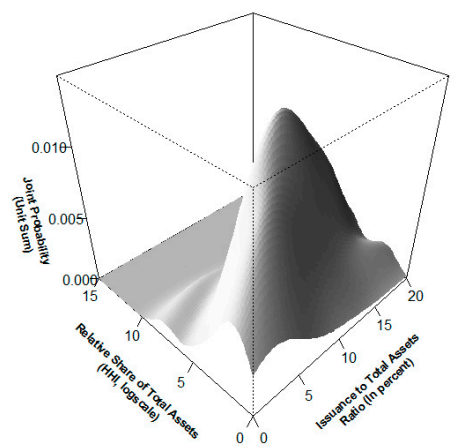

Malaysia

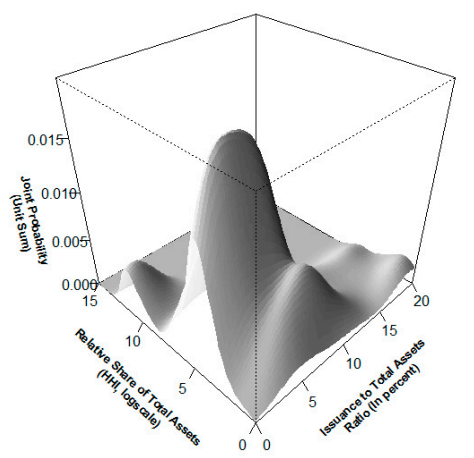

Thailand

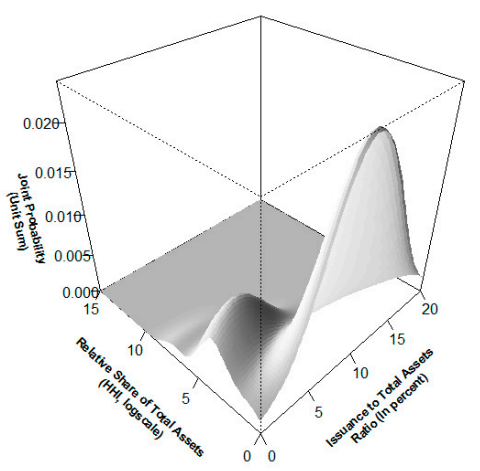

Korea

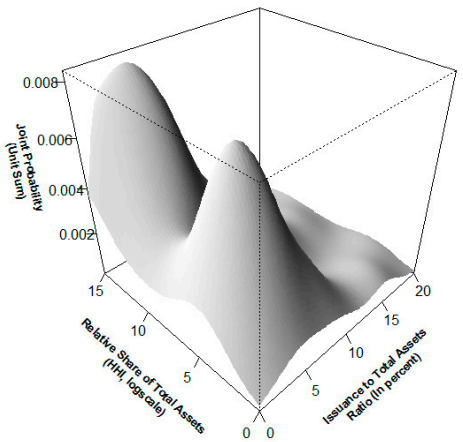

The bivariate density function plots the ratio of annual issuance over total assets (x-axis) over the relative share of individual total assets of each issuer (as a re-scaled HHI concentration measure, y-axis), which span the two-dimensional grid of joint probabilities (defined as the integral over the unit square [0,1], z-axis). Sources: Bloomberg, Worldscope, Moody's KMV as well as national stock exchanges. Note: $1 /$ Scaled Herfindahl-Hirschman Index (HHI): $\left(\Sigma(\text { market share of issuer })_{i}^{\wedge} 2-1 /\right.$ number of issuers $\left._{N}\right) /\left(1-1 /\right.$ number of issuers $\left._{N}\right)$ 
What do these developments imply for the standing of the ASEAN5 countries in the diagram presented at the beginning of this box? The answer is below:

Concentration of Issuers and Significance of Issues, 2005 and 2010

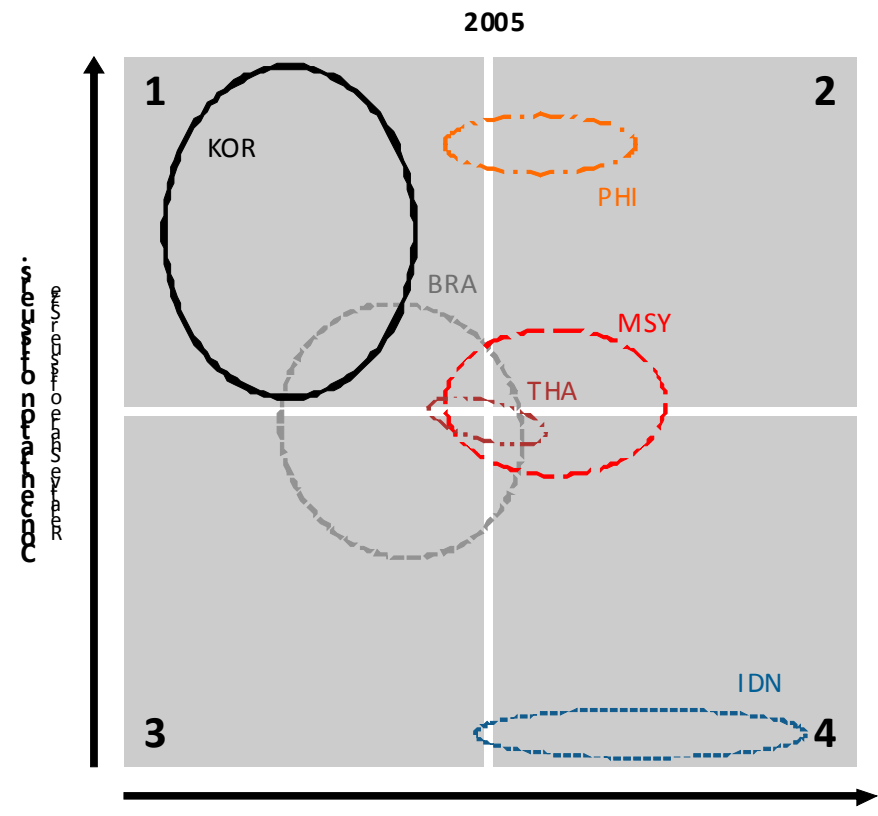

Balance Sheet Significance:

Issuance Relative to Individual Total Assets

2010

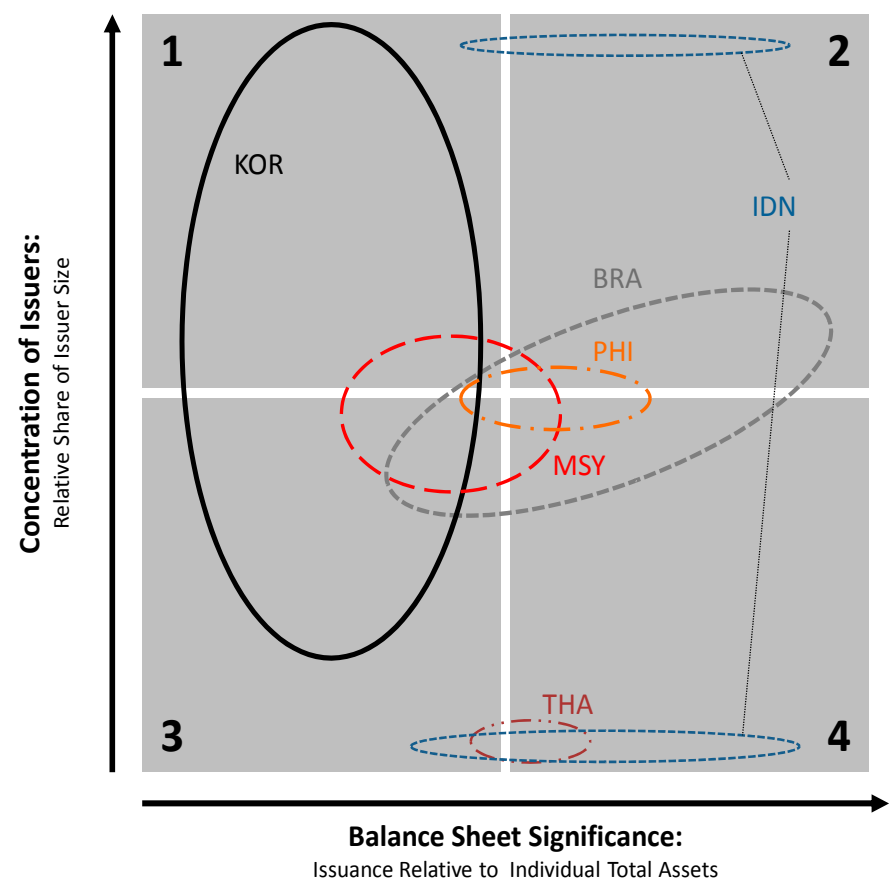


In the figure, the center of each ellipse represents the peak of the joint probability distribution of concentration and significance. Meanwhile, the size of each ellipse represents the relative issuance volume (Indonesia has two ellipses because it has two peaks in its probability distribution. Singapore is excluded from the chart.)

The picture conveys the same message as the summary statistics. Over the past decade, ASEAN5 countries - and emerging markets in general - have developed, in the sense of moving towards the low concentration-low significance third quadrant. Currently, the state of development in Malaysia and Thailand is not all that far from Korea and Brazil - at least as measured by these dimensions. Even so, none of the ASEAN5 countries have firmly entered the third quadrant. So, more progress needs to be made in diversifying the issuer base, and ensuring that issuance becomes a more routine method of financing operations.

The conclusions of the firm-level analysis can be summed up simply. The amount of issuance has risen steadily, as has the number of issues. Moreover, there has been progress in reducing concentration. A decade ago, only the largest and best-known firms were able to issue bonds, so their issues dominated local markets. Gradually, however, more and more firms have been able to issue, creating broader markets than before. This qualitative progress has culminated in two critical developments.

\section{The New Spare Tire}

Amidst the depths of the global financial crisis, there was a sudden surge in domestic bond issuance by emerging Asian corporates. For years, the stock of Emerging Asian corporate bonds outstanding had been stagnating as a percent of GDP. But in the second quarter of 2009, the stock increased by nearly 10 percent $\mathrm{q} / \mathrm{q}$ in the ASEAN5 and more than 20 percent q/q in emerging Asia excluding China. In the third quarter, there was a further large increase. By the end of the year, ASEAN5 local currency corporate bond issuance had reached a $\$ 58$ billion, higher than the previous peak,

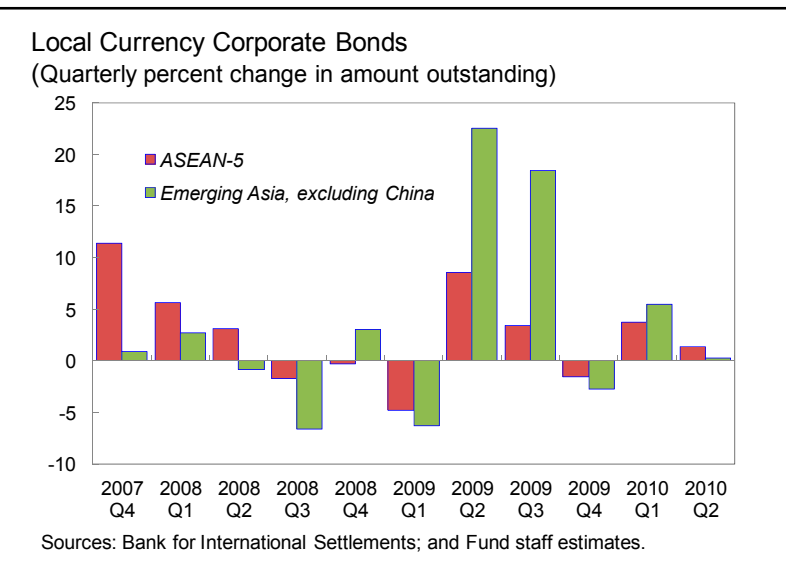
reached in 2007, and roughly double the normal level.

This surge was striking for a number of reasons. To begin with, as noted in Section III, ASEAN5 corporates typically do not rely much on bond issuance for funding. Moreover, the surge took place in the middle of a severe recession, when private sector investment had fallen sharply. So, firms had little need to issue bonds in order to finance investment projects - they were not initiating new ones and they were slowing down the ones that were already underway. Nor were firms forced to issue bonds just to sustain themselves; corporate profitability actually held up reasonably well during the recession. 
So, what explains the issuance boom? The primary factor appears to have been the behavior of local banks. Normally, bank-centered financial systems maintain their lending ties to their clients, even during difficult times. But this was not a normal downturn. Even though liquidity in the Asian banking systems was ample and capital adequacy was never in doubt, Asian banks nonetheless followed their Western peers and became more cautious after Lehman's bankruptcy. They tightened their lending standards and reduced their prime lending rates much more slowly and partially than the

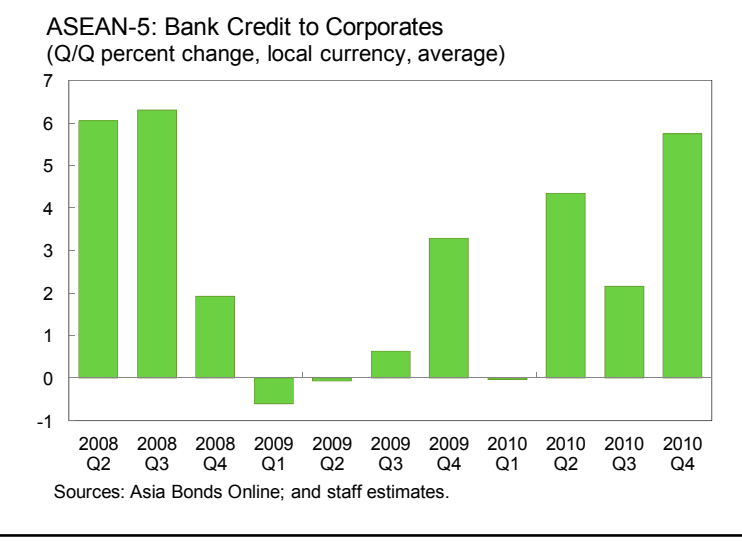
decline in policy and bond interest rates. Both measures encouraged firms to turn to the capital markets, while reducing their use of bank credit. In fact, adding the two sources of funding together, total credit to the corporate sector actually declined in the first half of 2009 in the ASEAN5 countries. So, the bond issuance was not "additional"-corporates were merely substituting one form of financing for another. In other words, the domestic bond market acted precisely as reformers had original hoped it would: it became the "spare tire" that corporations could use once the bank financing channel became impaired.

Two important caveats must be noted. First, as always, the bond market could be utilized only by larger companies. So, governments were compelled to step in to help SMEs, expanding programs that guarantee bank lending and providing funds directly through statecontrolled banks. Second, the bond market was not available when it was needed most. In fact, in the last quarter of 2008 and the first quarter of 2009, when the crisis was at its peak, market access effectively shut down. Still, it is striking that bond finance came back more quickly than bank finance, which started a sustained increase only in the second quarter of 2010.

Where was the demand for these bonds coming from? Much of the demand appears to have come from overseas, as global risk appetite began to revive with the stabilization of advanced country financial systems and as prospects in emerging markets appeared better than in the West. As a result, inflows into emerging market debt funds resumed in May 2009, and quickly reached levels approaching the peak of the 2005-07 global boom. In short, ASEAN5's domestic bond markets were able to become a spare tire during the Great Recession - one of the key original objectives -- because of another accomplishment. Foreigners were now willing to purchase domestic currency bonds, reducing the risk that corporates would be forced to endure a currency mismatch in order to secure bond financing.

This development raises two critical questions. Were the foreign purchases during the global crisis merely a temporary phenomenon, or did they truly reflect a durable shift in foreign investor behavior? And if foreign investor behavior has changed fundamentally, how did this happen? 


\section{The Rise of Foreign Investment}

After the Asian crisis, Eichengreen and Hausman (1999) argued that emerging markets were beset by an "original sin". According to this theory, EM's would inevitably suffer from the double mismatch problem; there was nothing much that could be done. That is because foreign investors were wary of issuers from such countries. So, they were unwilling to purchase local currency bonds. The only way to convince them to provide the needed finance was to issue global bonds, denominated in foreign currency, bearing relatively short maturity, and subject to the legal jurisdiction of an overseas financial center.

This model was based on the Latin American experience, and it was never entirely clear how well it applied to ASEAN. After all,

ASEAN did not have a history of hyperinflation, exchange rate instability, or defaults that had deterred investments in Latin America. Still, it remained true that foreign investment in ASEAN5 bonds was minimal. Even as recently as the middle of 2004, foreigners accounted for less than 2 percent of holdings of ASEAN5 government bonds. ${ }^{8}$ But the situation is rapidly changing. While overall capital inflows to the region in 2010 rebounded to about their 2006-07 levels, the composition shifted radically, toward portfolio investment and away from bank loans and FDI. And of the overall portfolio investment, bond inflows for the first time outpaced equity flows. ${ }^{9}$

\section{During the third quarter of $\mathbf{2 0 1 0}$, in particular, this torrent turned into a flood:}

- $\quad$ For example, in Thailand, which traditionally had only minimal foreign holders of its domestic bonds, overseas purchases in the third quarter of 2010 amounted to nearly $\$ 5$ billion, double the purchases for the first two quarters combined. ${ }^{10}$

- $\quad$ Meanwhile, in September 2010, the Philippines raised \$1 billion from its first global sale of peso-denominated bonds. ${ }^{11}$ In this way, the government was able to enhance its debt investor profile, while improving participation by offshore investors in

\footnotetext{
${ }^{8}$ Based on available data, from Indonesian, Malaysia, and Thailand.. These numbers may understate foreign interest, as foreigners were also gaining exposure to local markets through "access products". See Section V.C.

${ }^{9}$ Data on the composition of inflows is not available for Singapore.

${ }^{10}$ Overseas holdings of Thai government bonds jumped from $4 \frac{1}{4}$ percent of the stock outstanding as of endJune 2010 to 6 percent at end-September, then reached 7 percent by end-December.

${ }^{11}$ While denominated in pesos, the debt will be settled in U.S. dollars. To increase its attractiveness, the bonds were exempted from the 20 percent interest withholding tax.
} 
Philippine capital markets and providing overseas Filipinos with attractive and relatively safe alternative investment facilities.

Is this merely a cyclical phenomenon? Certainly, the extraordinary surge in foreign bond purchases stems from the unusual nature of the global recovery, which combines exceptionally low interest rates in advanced countries with bright growth prospects in emerging markets. In particular, there seems to be a considerable amount of "hot money", flowing in to local currency bond markets in the expectation that the gains from the interest differential will be amplified by those from currency appreciation. Such inflows could easily subside or reverse once cyclical conditions change.

But more long-lasting structural factors are also at work. Foreign holdings of emerging market local currency bonds have actually been increasing for some time, starting well before the global crisis. By 2007, foreign holdings had passed 8 percent; by, 2008, they had reached 12 percent; and after a brief dip during the global crisis, they surged, to 18 percent by the end of 2010. ${ }^{12}$ Moreover, ASEAN is only following, with a lag, a more general emerging market trend. For example, foreign holdings reached one-quarter of the debt stock by 2001 in
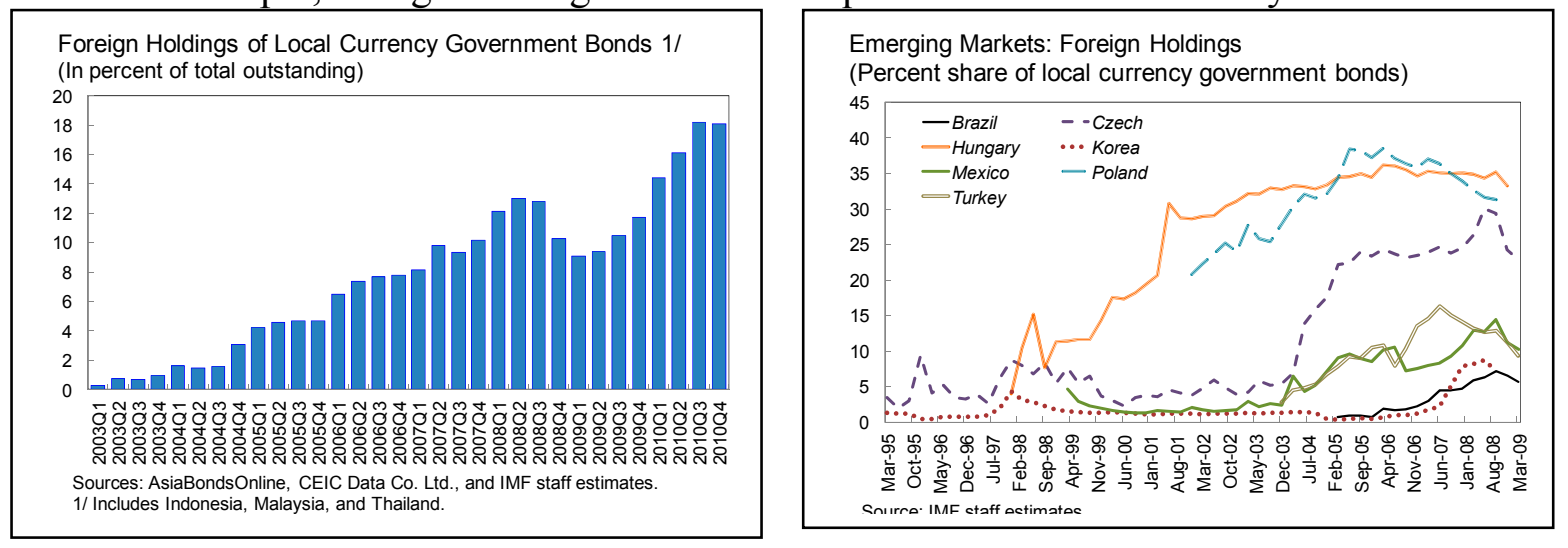

Hungary; by 2003 in Poland; and by 2005 in the Czech Republic.

\section{As foreign purchases of domestic bonds} have increased, issuance of foreign currency bonds has receded. The high-water mark of foreign currency corporate bonds came in 2002, when the amount outstanding reached 6 percent of ASEAN5 GDP, implying that more than one-third of total corporate bonds were denominated in foreign currency. But in the subsequent years, the share of foreign bonds gradually fell, so much so that by the

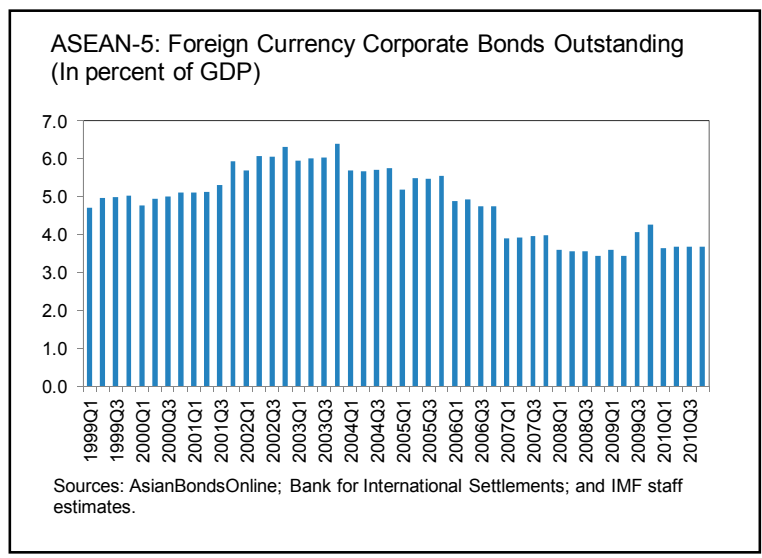

\footnotetext{
${ }^{12}$ To put this in a broader context, the Committee on the Global Financial System found in 2007 that foreign holdings of local debt instruments had increased sevenfold between 2002 and 2006 in selected EM countries.
} 
first quarter of 2010, it amounted to one-fifth of the total. ${ }^{13}$ (That said, it should be noted that foreign currency corporate issuance, like that of domestic currency issuance, surged during 2009 and remained high in 2010).

What explains these developments? Two factors. One is the development of corporate bond markets themselves. As they have expanded (in nominal terms, even if not relative to GDP), and become more accessible, and liquid foreign investors have been much more interested in entering these markets. In addition, macroeconomic fundamentals have improved. In an empirical paper, Hausman and Panizza (2003) argued that the degree of original sin was positively related to the level of development (proxied by GDP per capita), the strength of

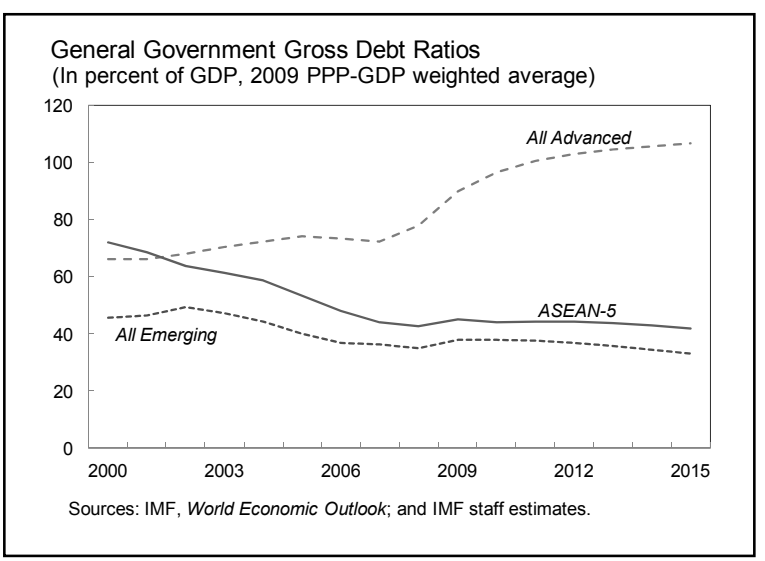
macroeconomic fundamentals (inflation and government debt), exchange rate flexibility, and the size of the investor base. ${ }^{14}$ Strikingly, ASEAN5 countries have made considerable progress along every one of these dimensions in recent years. In particular, economic fundamentals have improved to the point where in some ways they are now much stronger than in advanced nations, whose fiscal positions have deteriorated in the wake of the financial crisis. The average ASEAN5 government debt to GDP ratio is less than half the advanced country average, and the gap is only projected to widen in the coming years, as advanced country debt is projected by the IMF to climb further, reaching 108 percent of GDP by 2015. Yet long-term bond interest rates are higher in ASEAN5 countries, and prospects for currency appreciation arguably stronger.

This trend of improving relative fundamentals has applied to most emerging markets. One simple metric of this improvement is the aggregate rating of the bonds in the J.P. Morgan emerging market debt indices. In the 1990s, the rating for the EMBIG index of sovereign and corporate foreign currency emerging market bonds hovered between $\mathrm{BB}$ and BB- for the entire decade. But starting in 2002, it began an upwards march, to the point where it has now reached BBB- ${ }^{15}$ In fact, all three J.P. Morgan emerging market bond indices are now rated investment grade: the CEMBI (for corporate debt) is at BBB and the GBI-EM (for local currency debt) is rated A-.

\footnotetext{
${ }^{13}$ For comparison, according to the BIS, at end-2008 the outstanding stock of emerging market issued in major international markets (i.e., international bonds) amounted to about $\$ 1$ trillion, while bonds issued in domestic markets amounted to $\$ 6$ trillion.

${ }^{14}$ Burger and Warnock (2009) have a different list. They find that countries with higher scores on capital mobility, market liquidity and efficiency, regulatory quality and creditor rights, market infrastructure, taxation on bonds, and the size of the local institutional investor base, tend to attract great cross-border participation.

15 The improvement would have been even greater, except that a number of highly rated countries such as Korea have graduated from the index.
} 
As fundamentals have improved, emerging market assets as an investment class have developed a favorable risk-return profile. In fact, in the six years before the global crisis emerging market investments delivered substantially higher returns than U.S. Treasuries with only marginally higher volatility - implying a superior risk-adjusted performance. Similarly, EM local debts and equities clearly outperformed European fixed income and mature market equities in risk adjusted returns. Even if one includes the crisis period, the same conclusions still hold. During 2008, emerging market local currency bonds (as measured by the J.P. Morgan GBI-EM index) lost 5 percent, while U.S treasuries gained 14 percent. But in 2009, the figures were roughly reversed. So, taking the past decade as a whole, the annualized return on the GBI-EM was 14 percent, with a Sharpe ratio (returns/volatility) of 1; while the return on U.S. treasuries was less than 7 percent, with a Sharpe ratio of only $0.7 .{ }^{16}$

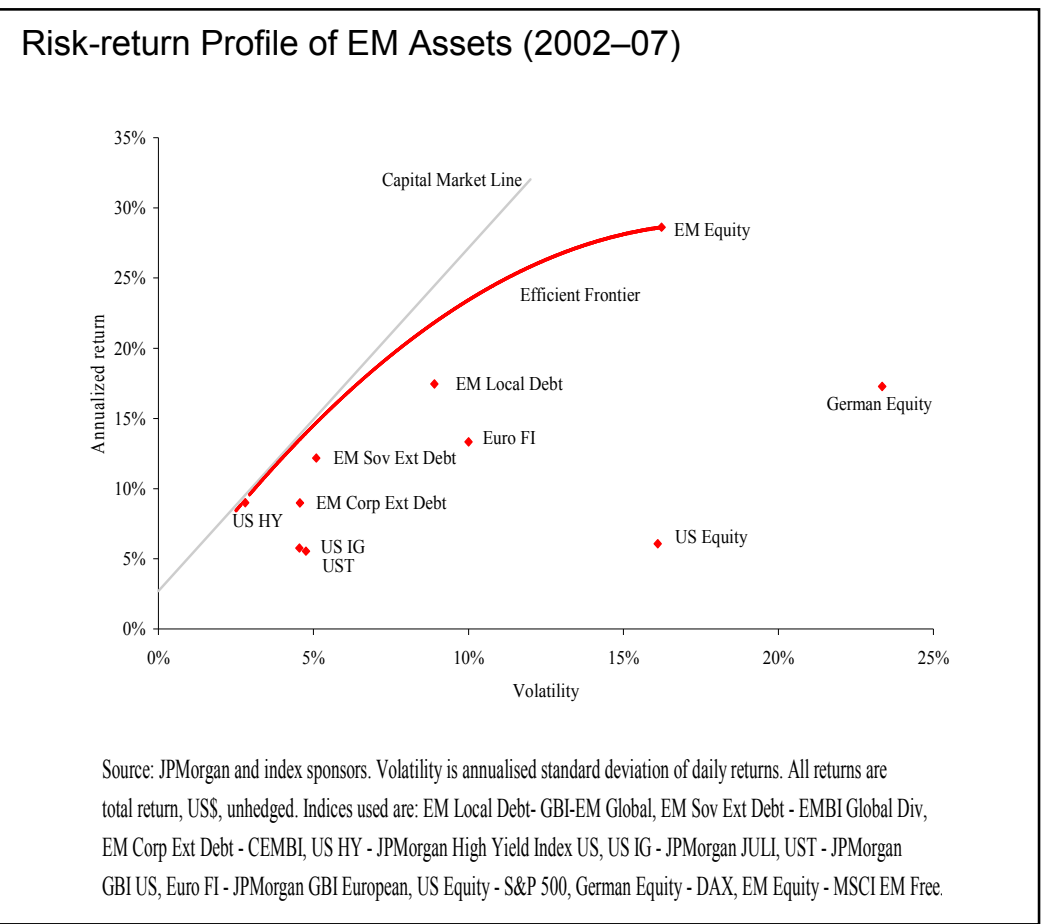

\section{This performance has not gone unnoticed. A} decade ago, dedicated emerging market debt funds were almost invisibly small. By 2005, they were receiving annual inflows of around $\$ 5$ billion per year. By 2010, inflows reached $\$ 35$ billion. Even allowing for the large cyclical element in recent flows, the underlying upward trend is clear. What will it imply for the future of ASEAN's bond markets?

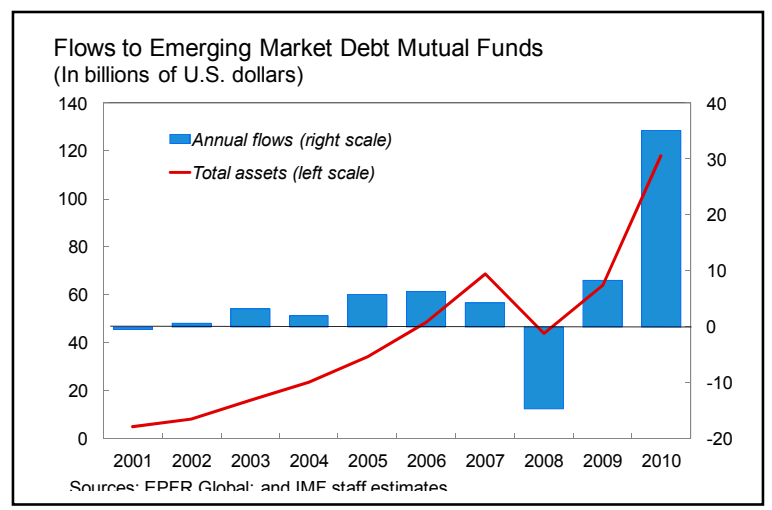

\footnotetext{
${ }^{16}$ Annualized returns from 2000 to September 30, 2010 for U.S. treasuries. For EBI-EM Global Diversified, data starts only in 2003 .
} 


\section{The Shape Of Things To Come}

The ramifications of growing foreign participation are difficult to predict. ${ }^{17}$ Precisely because there has been little foreign investment in domestic markets until recently, there is very little empirical evidence on the benefits and costs of foreign participation in bond market development (Daniel, 2008).

\section{A. Developmental Benefits}

Some potential benefits seem clear. To begin with, overseas firms could expand the investor base, compensating for the slow growth in traditional domestic investors, such as the contractual savings schemes. Indeed, the potential impact could be quite large. Market surveys by MSCI Barra and IMF (2010) indicate that global bond funds remain underweight emerging markets, providing scope for a continued stock adjustment into dedicated emerging market funds. And because global bond and hedge funds are very large relative to local bond markets, even a marginal increase in the weight of emerging markets in their portfolio could lead to a significant rise in demand. ${ }^{18}$

Over time, the shift in demand is likely to be much more than marginal. In fact, it is possible that emerging markets are now at the beginning of a secular trend, in which the share of emerging market assets in foreign portfolios will only grow, first as foreign investors gradually bring their portfolio weights up to the shares of these countries in the global economy, and as then these shares themselves rise, because of rapid growth. These trends are likely to be reinforced by the need of advanced country pension systems to improve their returns. In the U.S., the Pew

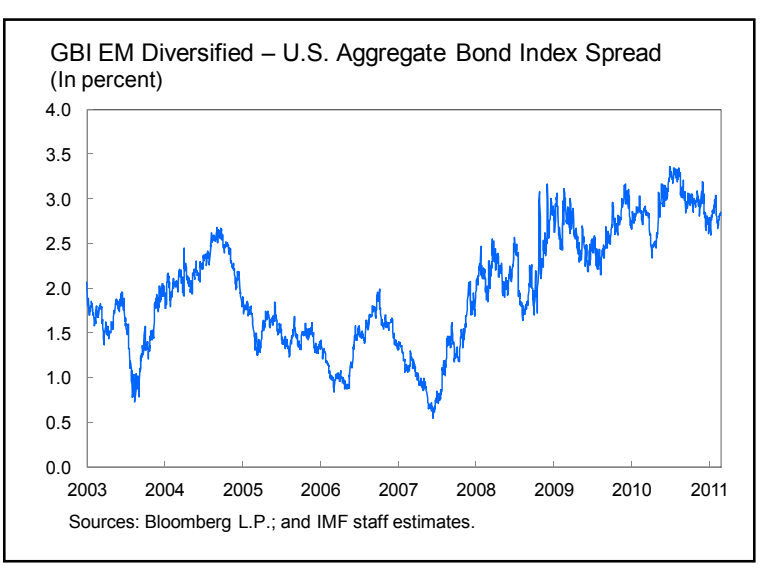
Center on the States (2010) has estimated that there is a $\$ 1$ trillion gap between the

\footnotetext{
${ }^{17}$ Increasing foreign inflows also pose broader macroeconomic policy questions. But such issues are beyond the scope of the current paper, which focuses squarely on the implications for bond market development.

${ }^{18}$ For example, IMF (2010) estimates that a 1 percentage point reallocation of global equity and debt securities held by G-4 real money investors, which amounts to about $\$ 50$ trillion, would result in additional portfolio flows of $\$ 485$ billion, larger than the record annual portfolio flows to emerging markets of $\$ 424$ billion recorded in 2007. Assuming that half of these inflows are allocated to debt (as has been the case recently), and that the debt flows are allocated proportionately to the bond stocks (excluding China), the ASEAN5 countries could receive an additional $\$ 50$ billion in investments per year.
} 
\$3.4 trillion in pension, health care and other retirement benefits that states have promised their workers and the $\$ 2.4$ trillion that they have set aside to pay for them. The need to close this gap will put growing pressure on pension funds - which currently invest little in emerging market debt - to increase their allocations, especially since the yields on such debt exceed the U.S. rates by a wide margin.

Intra-regional flows are compounding flows received from outside Asia. Some regional central banks have started buying their neighbors' financial assets in a bid to diversify reserve holdings, achieve a better risk-return profile, and contain sterilization costs. Individual investors have also been investing in Asian bonds through local mutual funds. Thai investors, for example, have in recent years been large accumulators of Korean bonds, while in the past two years the net purchases of Korean bonds by investors from other Asian countries (excluding Thailand) have actually exceeded purchases from the U.S.

Additional foreign demand could help reduce bond yields (IMF, 2005). To estimate how large this effect could be, Peiris (2010) employs a panel data framework to estimate the impact of foreign participation in determining long-term local currency government bond yields in a group of 10 emerging markets from $2000-09 .{ }^{19}$ This analysis suggests that greater foreign inflows do reduce government yields, after controlling for other domestic and external factors including global interest rates and risk aversion. This effect is reasonably large, with a 10 percentage point increase in the share of bonds held by foreign investors generating a decline in yields of about 60 basis points.

\section{Greater foreign participation will also}

improve liquidity. The larger the number of participants, the greater the diversity of preferences and views, which leads to more trading, better price discovery, and more efficient markets. Foreign participants are particularly beneficial for liquidity, since they are much more likely to trade domestic securities than domestic institutional

\footnotetext{
${ }^{19}$ The 10 EMs included are Brazil, Czech Republic, Hungary, Indonesia, Mexico, Malaysia, Korea, Thailand, Turkey, and Poland. These countries were selected because they had significant foreign participation in their domestic markets.
} 
investors, who typically follow buy-and-hold strategies. Case studies conducted by the World Bank and IMF (2001) on government bond markets in both emerging and mature markets confirm this effect qualitatively. The relationship between greater foreign participation and liquidity also appears to hold in the ASEAN5 region.

One reason why foreign participation tends to improve liquidity has to do with the nature of the foreign participants. Many of these are hedge funds, whose presence in emerging markets is expanding rapidly. From 2003 to 2010 assets under management by hedge funds dedicated to investing in emerging markets increased nine-fold to $\$ 95$ billion. ${ }^{20}$ Hedge funds are subject to few restrictions on their investment strategies. For example, they are not constrained by country ratings and thus can invest in countries with sub-investment grade ratings and even in countries that are not rated. Moreover, their use of leverage and more frequent trading amplifies their impact on trading volumes, especially in emerging market countries where they have tended to be both the early and larger players. Unsurprisingly, then, the Committee on Global Financial System (2007) estimated that hedge funds account for about 45 percent of trading volume in local emerging market debt.

Finally, greater foreign participation will create a virtuous circle that will expand the size of the debt markets themselves. As interest rates fall and liquidity improves, more firms will find it attractive to issue. And as more firms issue and market size grows, more investors will be enticed to participate. This will only reinforce the utility of the market as a spare tire. Since bond maturities are typically of longer duration than bank loans, the more ASEAN5 corporates shift to bond finance, the better their underlying liquidity situation will be, as they will have secured financing for longer periods. Consequently, they will face fewer difficulties if and when credit stops again. In other words, greater bond market development would not only ensure that the financial system will have a spare tire in case of another crisis. It will also give corporates a spare tire - greater liquidity - that it can use as insurance, even before the crisis takes place.

\section{B. Potential Costs}

What are the potential costs to bond markets of this increased foreign participation? To begin with, inflows into the bond market can complicate the conduct of monetary policy. Some of the problems are well-known, as they apply to any type of capital inflows, including the equity and bank inflows with which ASEAN5 countries are long familiar. But some of the complications are new.

\footnotetext{
${ }^{20}$ In fact, dedicated emerging market hedge funds tend to invest primarily in equities, while macro hedge funds (with no particular mandate to invest in emerging markets) tend to invest in bonds. But the expansion of the assets of the former type gives some indication of the increase in hedge fund interest in emerging markets.
} 
In particular, if inflows are channeled into domestic government bonds, then long-term rates will be affected. It is difficult to say, $a$ priori, whether this helps or hinders central bank operations. To the extent that bond markets become more liquid, and attuned to central bank signals regarding future interest rates (as opposed to being dominated by institutional investors which need to buy longterm assets to match their liabilities) then transmission mechanisms could be improved. However, to the extent that yield curves become dominated by developments elsewhere in the world then monetary

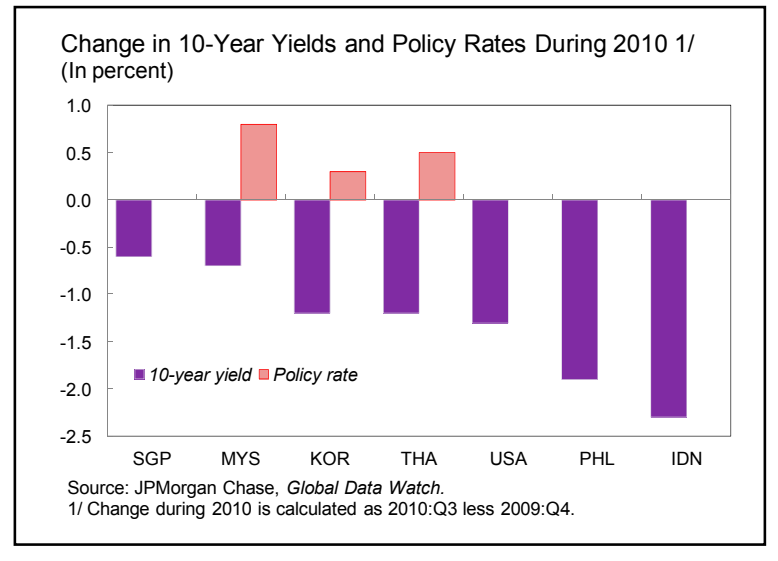
independence will be reduced. Indeed, during 2010 ASEAN5 countries were confronted with flattening yield curves -- the "Greenspan dilemma" of the mid-2000s: even as some countries raised short-term rates, foreign purchases were causing long-term rates to fall.

Another potential risk is greater interest rate volatility. ${ }^{21}$ Surges in foreign inflows are often followed by sudden withdrawals, as ASEAN discovered in 1997. More recently, after the collapse of Lehman Brothers in September 2008, net capital inflows to emerging markets suddenly shifted into reverse as portfolio capital started to flow out of these countries, a process which continued for the next two quarters. Then, in the second quarter of 2009 following extraordinary macroeconomic easing and policy support to

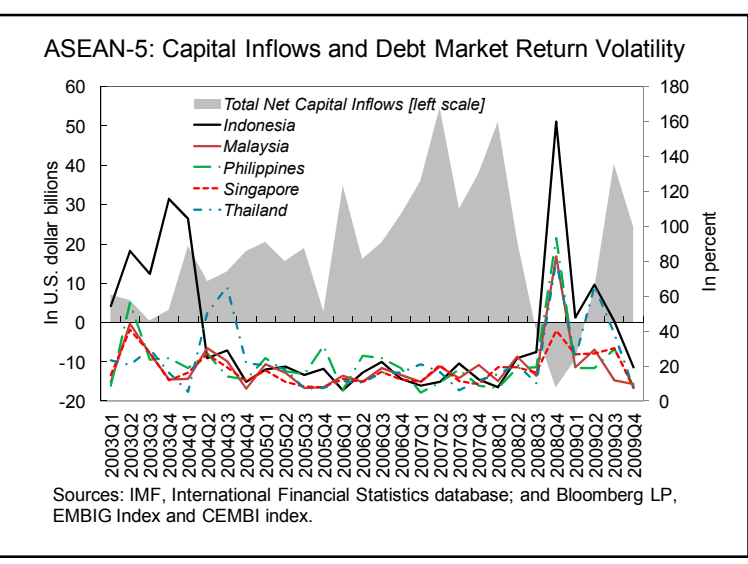
shore up advanced country banking systems, capital inflows resumed, quickly reaching 2006 levels. For ASEAN countries the adjustment was even more profound, as inflows turned negative for three quarters and then recovered much more slowly.

\section{Assessing the implications of these swings in capital flows, however, is far from} straightforward. After Lehman, the volatility of debt market returns increased sharply in some ASEAN5 countries, especially Indonesia, which has a particularly high level of foreign participation. But volatility also increased in countries with low foreign shares, while rising only minimally in Singapore, the most open of all the five countries. In fact, the increase in volatility was correlated much more closely with the degree of market development than it

\footnotetext{
${ }^{21}$ Of course, there could be wider costs to the economy, including through movements in the exchange rate. But as mentioned above, these considerations are beyond the scope of the paper.
} 
was with foreign participation. Perhaps this is because countries with a greater institutional footprint in local currency debt were better able to temper the effects from foreign short-term investors scaling down their exposures to the region.

Even if foreign participation and yield volatility are related in the short run, over the longer term, the relationship may be much weaker - or even non-existent. That's because, as Prasad and Rajan (2008) have noted, foreign participation can actually be a stabilizing force for local markets. Foreign investors frequently exert pressure for more transparency which reduces price volatility because it improves the quality and increases the frequency of information. Such changes reduce the risk that there will be sudden disclosures of accumulated negative news. Moreover, in cases where they do occur, foreign participation attenuates the price impact, because it broadens what would

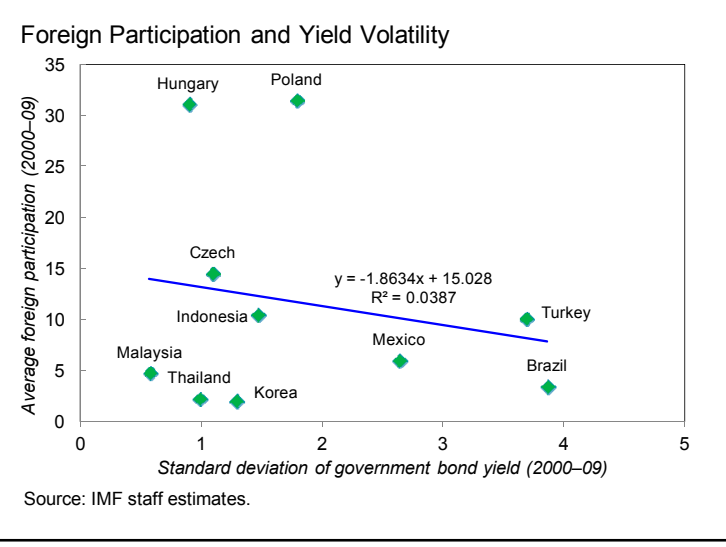
otherwise have been a thinner market. In fact, a cross-sectional analysis of 10 emerging markets with significant foreign participation in the local currency government bond market found no clear correlation between foreign participation and bond price volatility over $2000-09 .{ }^{22}$

Finally, there are some concerns that bond flows are more prone to destabilizing reversals than investments in equities, presumably because the stronger domestic repricing of equities endogenously moderates outflow pressures. Yet the empirical evidence that bond flows are more volatile than equities is weak.

\section{That said, risks from bond flow volatility remain significant, for several reasons:}

- $\quad$ Surging bond yields can cause considerable domestic dislocation, arguably far more than falling equity prices.

- While long-term investors have begun to diversify their portfolios toward emerging market assets, the bulk of the recent inflows appear to have been led by investors with much shorter horizons, such as hedge funds. Moreover, as noted above, much of the inflows have had a cyclical element, as investors have responded to large interest rate differentials between ASEAN5 countries and the U.S., Europe, and Japan by shifting

\footnotetext{
${ }^{22}$ Similarly, a time-varying volatility model of long-term government bond yields in 10 EMs from 2000-09 in Peiris (2010) shows that foreign presence does not necessarily result in greater volatility in local government bond markets, in part because domestic markets seem to then "import" low levels of volatility during the (much longer) periods of tranquility in international markets.
} 
investments into the former. ${ }^{23}$ Work at the IMF (see the April 2011 WEO, forthcoming) suggests that when relative monetary conditions change - when the U.S. begins to raise interest rates - there could be a sizeable reduction in inflows to emerging markets.

- $\quad$ Not all ASEAN5 countries have reached investment grade. It is possible that countries with sub-investment grade rates may be particularly affected when foreign portfolio inflows diminish, especially if this change is the result of a renewed rise in risk aversion.

Is there a way to secure the longer-term benefits of greater foreign participation, while reducing the potential short term volatility costs? Again, because the demise of "original sin" is so recent, there is little international experience that can be drawn upon for lessons. One potentially significant measure was taken by Indonesia in July 2010. At that time, foreign investment had been pouring into SBIs (central bank securities), in part because of carry-trade activity by hedge funds, in which investors borrow in currencies such as the U.S. dollar where interest rates are low in order to invest in currencies such as the rupiah, where interest rates are high. Since these investments are financed using borrowed money, investors are forced to liquidate their positions whenever funding costs rise or financing conditions change. That means that such investments can be volatile. To reduce the attendant risks, Indonesia imposed a one-month holding period on SBIs, applicable to domestic and foreign holders. In principle, this measure should circumscribe the scope for foreign outflows when global risk aversion rises, since investors will no longer be able to exit their SBI positions quickly. Precisely for that reason, it should also discourage short term carry trade inflows in the first place. ${ }^{24}$

The question is how effective the measure will prove in practice. So far, there's no evidence that it has affected aggregate foreign holdings of Indonesian securities, which initially fell but then quickly reversed course, surpassing their July level on their way to reaching new heights. Nor is it clear how well the measure will succeed in limiting outflows, since investors wish to exit their positions, they could hedge them by selling other Indonesia assets.

\section{There may also be some unanticipated side} effects. For example, the associated decision to

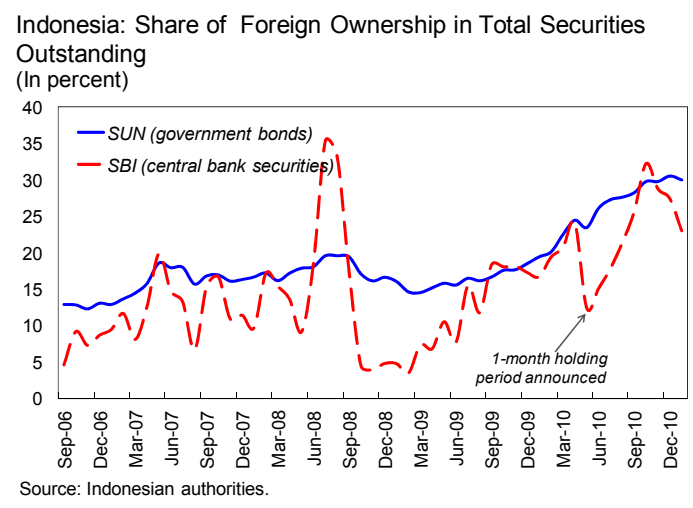

eliminate the 3-month SBI appears to have impeded the development of the nascent interest rate swap market by eliminating its

\footnotetext{
${ }^{23}$ Investors have also been attracted by the expectation that regional currencies will appreciate.

${ }^{24}$ Holding restrictions could also discourage investments by ordinary long-only open-ended mutual fund because daily redemptions require the ability to sell securities.
} 
benchmark rate. (Central bank term deposits exist, but may not be an adequate substitute because they are not traded.) Consequently, it may take some time before the measure can be properly assessed.

\section{Dealing with Off-shore Activity}

The rise of foreign interest in domestic bonds has another important ramification: growing off-shore activity. Foreign investors are increasingly obtaining exposure to emerging markets by using various "access products", such as over the counter derivatives, structured securities, or offshore special purpose vehicles. Modes of access include innovative financial instruments such as non-deliverable forwards and other derivative instruments, including credit-linked notes. Partly as a result of these activities, derivatives transactions with emerging market assets as underlying have exploded in recent years.
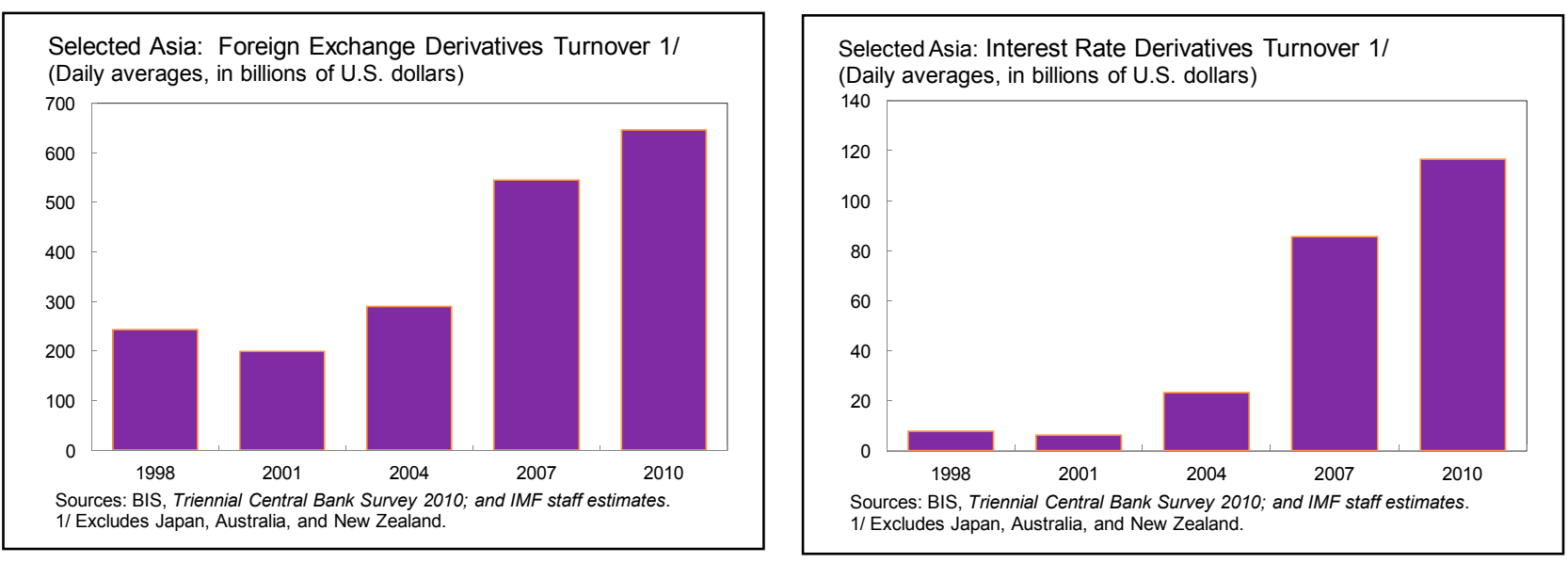

Why do foreign investors transact off-shore? In part, because there are advantages to doing so. For example, by staying off-shore they can assume counterparty risk vis-a-vis a few familiar developed market financial institutions, avoiding the need for dealing with (and conducting extensive due diligence on) a variety of less familiar firms from a multitude of emerging market countries. But investors also stay offshore because there are impediments or costs to entering the onshore markets.

\section{Impediments can come in a variety of forms, such as: ${ }^{25}$}

- $\quad$ Limits on access to money market or other short-term instruments.

- Clearing and settlement protocols and custody arrangements, such as custody controls, directed settlement, and rules on sub-custody. The cost of appointing a local custodian can make cross-border investments unattractive.

- $\quad$ Minimum holding periods.

\footnotetext{
${ }^{25}$ The nature and extent of impediments differ widely from country to country. For example, Malaysia has none of the impediments listed below. In fact, Malaysia has made its bond market internationally accessible via international central securities depositories (Euroclear and Clearstream) to enable foreign investors to settle securities transactions without the opening of a local custodian account.
} 
Does any of this matter? It does, for several reasons. Controls and taxes that drive activity off-shore fragment the market and reduce liquidity on-shore, thereby impairing price discovery. In other words, they reduce efficiency. They also reduce transparency. For example, with much of the activity taking place beyond their jurisdiction, in relatively opaque over-the-counter markets, national authorities will find it difficult to monitor market developments. They will also have difficulty assessing the investor base, since domestic data on foreign ownership will no longer be a good indicator of the actual level of foreign participation, particularly for the hedge funds and proprietary trading desks that typically use access products. Indeed, a significant proportion of bonds owned by the domestic financial sector may actually be held on behalf of foreign investors (typically by onshore banks) through derivative structures.

A shift towards offshore activity may also raise prudential concerns. Offshore markets may be less regulated, and in any case will not be regulated by the home authorities. Moreover, even though controls might exist that aim to isolate domestic markets from those offshore, inevitably firms find ways to arbitrage between the two. As a result, developments in markets offshore can be transmitted onshore. In that case, compensating policy action might prove difficult because national authorities may not have much information on the genesis or the nature of the underlying shock. This is a particular concern since the leverage that underlies access instruments can be an important driver of market volatility.

For all these reasons, over time it may be beneficial to try to bring such markets onshore. One way to do this is by reducing or eliminating withholding taxes. Such a measure, however, would raise difficult issues of equity and efficiency. For example, if nonresidents are exempted from withholding tax, this could lead to practices such as "coupon washing", where bonds are sold over the coupon payment period - perhaps via repo - to investors paying low or zero withholding tax. Alternatively, resident investors may begin to route purchases through offshore routes to avoid or reduce the cost of withholding tax. On the other hand, if withholding tax on bonds is abolished for all, residents and non-residents alike, then this might create a distortion favoring bond markets over equity markets.

\section{Conclusion}

Over the past decade, exceptional efforts by country authorities to expand ASEAN5's bond markets have been undercut by broader macroeconomic trends. Firms have had very little need to issue, since they have dramatically improved their profitability, while reducing their investment ratios. As their cashflows have improved, they have used the spare funds to reduce their leverage - that is, to pay down their debts, rather than to borrow more. Meanwhile, on the demand side, the domestic investor base has grown, but until recently foreigners have remained reluctant to purchase local currency bonds.

Recently, however, one of these trends has turned decisively. Foreigners have become increasingly willing, even enthusiastic, about buying domestic bonds. Their funding has already enabled ASEAN5 bond markets to act as a spare tire for the domestic financial system to, provide finance to companies during a period where banks remained reluctant to lend. As this new trend continues, bond markets should be able to become much more than a spare tire. With foreign investors increasing the share of emerging market assets in their 
portfolios to match their weight in the global economy, the additional demand is likely to reduce interest rates, improve liquidity, and thereby encourage firms to issue, expanding the market size. In other words, foreign participation is likely to trigger a virtuous circle of bond market development, to the point where ASEAN could over the next decade develop the long-envisioned "twin engine" financial system.

These new trends, however, will bring new challenges in their wake. As foreign demand for emerging assets grows, capital inflows will increase, complicating the conduct of monetary policy. Volatility may increase since surges in inflows could be followed by large outflows, a risk that may be particularly large because so much of the portfolio inflows could be leveraged, and so are particularly sensitive to changes in global risk aversion. Finally, the proliferation of access products, enabling investors to gain exposure to emerging market assets without buying them directly, has caused markets to develop offshore, meaning that developments in the domestic market no longer give authorities the full picture of underlying market forces.

It is too early to know how policies should respond. It will take some time for the new trends to play out. But two broad directions seem clear. Measures will be needed to deepen local capital markets further, so that financial systems can act as a better shock absorber against capital flow volatility, thereby limiting its impact on the real economy (See the companion paper, "Developing Bond Markets: What Still Needs to be Done?"). Also, it may be worthwhile trying to bring markets onshore, by removing barriers to entry, including withholding taxes.

In sum, ASEAN5's strenuous efforts of the past decade have indeed succeeded in transforming its bond markets. But the developments of the past ten years may well be dwarfed by changes that may take place in the decade ahead. Time will tell. 


\section{REFERENCES}

Bae, Kee-Hong, Young-Sup Yun and Warren Bailey, 2006, "Determinants of Bond Holdings by Foreign Investors", in Asian Bond Markets: Issues and Prospects, BIS Papers 30.

Burger, J. D., and F. E. Warnock, 2007, "Foreign Participation in Local Currency Bond Markets", Review of Financial Economics Vol.16, pp. 291-304.

Committee on the Global Financial System, 2007, "Financial Stability and Local Currency Bond Markets" CGFS Paper 28.

Daniel, L., 2008, Foreign Investors' Participation in Emerging Market Economies' Domestic Bond Markets, Banque de France, Bulletin Digest No. 173.

Eichengreen, Barry, 2006, "The Development of Asian Bond Markets" in Asian Bond Markets: Issues and Prospects, BIS Papers 30.

Eichengreen, Barry and Ricardo Hausmann,1999, "Exchange Rates and Financial Fragility", In New Challenges for Monetary Policy. Proceedings of a symposium sponsored by the Federal Reserve Bank of Kansas City.

Eichengreen, Barry and Pipat Luengnaruemitchai, 2006, "Why Doesn't Asia Have Bigger Bond Markets?" in Asian Bond Markets: Issues and Prospects, BIS Papers 30.

Espenilla, Jr, Nestor A., 2006, "The Corporate Bond Market in the Philippines" in Developing Corporate Bond Markets in Asia, BIS Papers 26.

Greenspan, Alan, 1999, “Do Efficient Financial Markets Mitigate Financial Crises?” Speech before the 1999 Financial Markets Conference of the Federal Reserve Bank of Atlanta, Sea Island, Georgia (October).

Gyntelberg, Jacob, Guonan Ma and Eli Remolona, 2006, "Developing Corporate Bond Markets in Asia," in Developing Corporate Bond Markets in Asia. BIS Papers 26.

Hausmann, Ricardo and Ugo Panizza, 2003, "On the determinant of Original Sin: An Emprical "Investigation", Journal of International Money and Finance. Vol. 22 pp. 957-90.

Ibrahim, bin Muhammad and Adrian Wong, 2006, "The corporate bond market in Malaysia," in Developing Corporate Bond Markets in Asia. BIS Papers 26.

International Monetary Fund, 2005, Global Financial Stability Report "Development of Corporate Bond Markets in Emerging Market Countries" (Washington).

— 2010, Global Financial Stability Report (October).

_ 2010, Asia-Pacific Regional Economic Outlook (October).

Lee, Chuan Teck, 2006, “Developing Singapore's Corporate Bond Market” in Developing Corporate Bond Markets in Asia, BIS Papers 26. 
Mieno, Fumiharu, 2008, Jiyuka kaikaku kara ikusei e: Higashi Ajia no kin'yuushisutemu o meguru seisakuron to sono henten (From liberalization and reform to development: Changes in policy discussions relating to East Asia's financial system). In Gendai Ajia kenkyu gensho: Seisaku hen (Studies on Modern Asia: Policies), eds. Yasuhiro Takeda, Tomoo Marukawa, and Shanping Yan, pp. 115-183. (Tokyo: Keio University Press).

__ 2009, Tai, Mare-shia ni okeru kigyo no bunpu to shikinchotatsu: Jojo/hijojo, gaishikei, Nikkei kigyo o shoten ni (Corporate distribution and financing in Thailand and Malaysia: A study on corporations from the perspectives of listed and non-Listed, foreign affiliated, and Japanese affiliated). Journal of JBIC International Research Office 2, Japan Bank for International Cooperation International Research Office.

Mieno, Fumiharu, Mamoru Nagano, Kenichi Takayasu, Masahiko Takeda and Shigeto Nagai, (2009), "Developing Bond Markets in Asia", Study Group on the Asian Financial System Center for Monetary Cooperation in Asia, Bank of Japan.

Peiris, Shanaka J., 2010, "Foreign Participation in Emerging Markets' Local Currency Bond Markets", IMF Working Paper WP/10/88 (Washington: International Monetary Fund).

Pew Center on the States, 2010, The Trillion Dollar Gap: Underfunded State Retirement Systems and the Road to Reform

Prasad, Eswar and Raghuram Rajan, 2008 "A Pragmatic Approach to Capital Account Liberalization," Journal of Economic Perspectives, American Economic Association, vol. Vol. 22 No. 3, pp 149-72, (summer).

Spiegel, Mark M., 2009, "Developing Asian Local Currency Bond Markets: Why and How" ADBI Working Paper Vol.182 (Japan).

Teranishi, Juro, Shinichi Fukuda, and Qun Liu. 2007. Higashi Ajia no kin'yuushisutemu no chiikiteki tokushitsu [Regional features of the East Asian financial system]. In Ajia no keizaihatten to kin'yuushisutemu Tohokuajia hen [Economic development and financial system of Asia: North East Asia], eds. Juro Teranishi, Shinichi Fukuda, Hidenobu Okuda, Fumiharu Mieno, ch.7. Tokyo: Toyo Keizai Shinposha.

Vann, Richard J., 1998, "International Aspects of Income Tax", in Tax Law Design and Drafting. (Washington: International Monetary Fund).

World Bank and International Monetary Fund, 2001, Developing Government Bond Markets: A Handbook, (Washington). 